Chapter 5

\title{
Weed and Disease Control and Peanut Response Following Post-Emergence Herbicide and Fungicide Combinations
}

\author{
W. James Grichar, Peter A. Dotray and \\ Jason E. Woodward \\ Additional information is available at the end of the chapter \\ http://dx.doi.org/10.5772/55949
}

\section{Introduction}

Peanut, or groundnut (Arachis hypogaea L.), is a species in the legume or "bean" family (Fabaceae). Hypogaea means "under the earth" [1]. Peanuts are known by many other local names such as earthnuts, goober peas, monkey nuts, pygmy nuts and pig nuts [2,3]. Peanut was probably first domesticated and cultivated in the valleys of Paraguay [3].

The domesticated peanut is an amphidiploid or allotetraploid, meaning that it has two sets of chromosomes from two different species, thought to be A.duranensis and A. ipaensis. These likely combined in the wild to form the tetraploid species, $A$. monticola, which gave rise to the domesticated peanut $[4,5]$. This domestication might have taken place in Paraguay or Bolivia, where the wildest strains are found today. Archeologists have dated the oldest specimens to about 7,600 years, found in Peru [3,4]. Cultivation spread as far as Mesoamerica where the Spanish conquistadors found the tlalcacahuatl (Nahuatl = "peanut", whence Mexican Spanish, cacahuate and French, cacahuète) being offered for sale in the marketplace of Tenochtitlan (Mexico City). The plant was later spread worldwide by European traders [3].

Peanuts grow best in light, sandy loam soil. They require 120 to 150 days of warm weather, and an annual rainfall of 380 to $650 \mathrm{~mm}$ or the equivalent in irrigation water [6]. It is an annual herbaceous plant growing 30 to $50 \mathrm{~cm}$ tall. The leaves are opposite, pinnate with four leaflets (two opposite pairs; no terminal leaflet), each leaflet 1 to $7 \mathrm{~cm}$ long and 1 to $3 \mathrm{~cm}$ wide. The orange-veined, yellow-petaled, pea-like flower ( 2 to $4 \mathrm{~cm}$ across) of $A$. hypogaea is borne in axillary clusters above ground. Following self-pollination, the flowers fade and wither. The stalk at the base of the ovary, called the pedicel, elongates rapidly, and turns downward. 
Continued stalk growth pushes the ovary underground where the mature fruit develops into a legume pod (the peanut). The fruits or pods have wrinkled shells that are constricted between pairs of the one to four (usually two) seeds per pod [4,5].

Harvesting occurs in two stages [6]. In modern, mechanized systems, a machine called a digger is used to cut off the main or tap root of the peanut plant by cutting through the soil just below the level of the peanut pods. The machine lifts the plant from the ground, shakes and inverts the plant, leaving it upside down on the ground to keep the peanut pods out of the soil. This allows the peanuts to dry slowly to a bit less than a third of their original moisture level over a period of three to four days depending on weather conditions [6]. Prior to mechanization, peanuts were pulled and inverted by hand [6]. The second stage consists of the use of a combine to remove peanuts from the vine.

World peanut production totals approximately 34 million metric tons per year (Table 1). China leads in production of peanuts, having a share of about $46 \%$ of overall world production, followed by India (17\%), and the United States (6\%) [7]. The United States is one of the world's leading exporters, with average annual exports of between 200,000 and 250,000 metric tons. Argentina and China are other significant exporters [7].

Peanut production requires the use of a wide range of agrichemical products to control weed and diseases and optimize crop growth and development [8-10]. Peanut has several unique features that contribute to challenging weed management [10]. Peanut cultivars grown in the United States require a fairly long growing season (140 to 160 days), depending on cultivar and geographical region [10,11]. Consequently, soil-applied herbicides may not provide season-long control and mid-to-late season weed emergence can occur. Peanut also has a prostrate growth habit, a relatively shallow canopy, and is slow to shade inter-rows allowing weeds to be more competitive [10,12]. Additionally, peanut fruit develop underground on pegs originating from branches that grow along the soil surface. This prostrate growth habit and pattern of fruit development restricts cultivation to an early season control option $[10,13]$. With conventional row spacing (91 to $102 \mathrm{~cm}$ ), complete ground cover may not be attained until 8 to 10 weeks after planting. In some areas of the United States peanut growing region, complete canopy closure may never occur.

Pigweed (Amaranthus spp.) is listed as one of the ten most common weeds in most peanutgrowing states in the United States, with Palmer amaranth (Amaranthus palmeri S. Wats) ranked as the fourth most common weed in South Carolina [14]. Palmer amaranth is not generally ranked as a troublesome weed in most crops in the United States; however, it is a common weed in many crops produced around the world. Palmer amaranth is currently found in the southern half of the United States [15] while in Texas, Palmer amaranth can be found in all areas of the state [16] and is a severe problem in many peanut fields when not properly controlled [17]. Texas millet (Urochloa texana (Buckley) R. D. Webster) is a large seeded, vigorous, fast growing annual grass commonly found in peanut fields in parts of Florida, South Carolina, Oklahoma, and Texas [14]. It is listed as one of the most troublesome weeds in all peanut growing states except Alabama and Georgia [14]. During the digging operation, the peanut plant is lifted out of the ground and inverted. A heavy stand of Palmer amaranth or Texas millet can reduce the effectiveness of the process. The tight fibrous root 
system becomes intertwined with the peanut plant, causing peanut pods to be stripped from the vine during digging. Peanuts that become detached from the plant remain unharvested in or on the soil [18].

\begin{tabular}{|c|c|c|}
\hline Rank & Country & $\begin{array}{c}\text { Production } \\
\text { (Million metric tons) }\end{array}$ \\
\hline 1 & China & 15.64 \\
\hline 2 & India & 5.85 \\
\hline 3 & United States & 1.89 \\
\hline 4 & Nigeria & 1.55 \\
\hline 5 & Senegal & 1.29 \\
\hline 6 & Indonesia & 1.25 \\
\hline 7 & Burma & 1.14 \\
\hline 8 & Argentina & 1.05 \\
\hline 9 & Sudan & 0.85 \\
\hline 10 & Chad & 0.47 \\
\hline 11 & Ghana & 0.44 \\
\hline 12 & Vietnam & 0.44 \\
\hline 13 & Congo Kinshasa & 0.37 \\
\hline 14 & Burkino Faso & 0.35 \\
\hline 15 & Mali & 0.28 \\
\hline 16 & Malawi & 0.27 \\
\hline 17 & Guinea & 0.26 \\
\hline 18 & Cameroon & 0.24 \\
\hline 19 & Brazil & 0.23 \\
\hline \multirow[t]{2}{*}{20} & Egypt & 0.19 \\
\hline & Total & 34.05 \\
\hline
\end{tabular}

Source: USDA Foreign Agricultural Service; Table 13 Peanut Area, Yield, and Production (Created 8/10/2012)

Table 1. Worldwide peanut production.

The dinitroaniline herbicides are registered for use in over forty crops [19]. These herbicides provide excellent control of annual grasses $[10,18,20]$ and are the only soil-applied herbicides registered for use in peanut that will provide full-season control of Texas millet $[10,21,22]$. Peanut tolerance to the dinitroaniline herbicides has been questioned previously $[23,24,25]$. Greenhouse studies showed that ethalfluralin inhibited seedling growth more than pendimethalin at equivalent rates applied preplant incorporated; however, injury by these herbicides following preemergence applications were similar [26]. In runner peanuts, which are more prone to peg injury compared to Spanish peanut [27], proper herbicide incorpora- 
tion was needed to prevent injury [28]. Merkle [27] stated that sporadic injury to runner peanut from trifluralin was due to the failure to properly incorporate the herbicide. No differences were observed in a study examining peanut growth, yield, and grade effects with ethalfluralin, pendimethalin, or trifluralin in two different studies [24,29]. In Florida, ethalfluralin did not cause peanut injury at any rate or application timing [23]. Dinitroaniline injury on peanut includes swollen hypocotyl, abnormal lateral root growth, and stunted plants $[18,28]$.

Metolachlor is commonly used in peanut for control of small-seeded broadleaf weeds, some annual grasses, and yellow nutsedge [30]. S-metolachlor is labeled for either preplant incorporated (PPI), POST-plant incorporated, preemergence (PRE), postemergence (POST), or layby in peanut [31]. The registered rate for the southwest United States is 1.1 to $1.4 \mathrm{~kg} / \mathrm{ha}$ [31]. However, many growers have reported peanut stunting when soil applications of metolachlor have been followed by rain [30]. Grichar et al. [30] reported that POST applications of metolachlor followed by (fb) irrigation within 24 hour could be effective for yellow nutsedge control and reduce the chance of peanut injury from soil applications of metolachlor. Combinations of factors, such as herbicide rate, moisture conditions at planting, soil organic matter, and $\mathrm{pH}$ may affect peanut injury by chloroacetamide herbicides such as $S$-metolachlor [32-35]. Cardina and Swann [32] reported that metolachlor often delayed peanut emergence and reduced peanut growth when irrigation followed planting. However, yield loss was observed only when metolachlor was applied at a $3 \mathrm{X}$ rate.

Several postemergence herbicides are used to control weed escapes. Imazethapyr and imazapic are imidazolinone herbicides registered for use in peanut. Imazethapyr may be applied PPI, PRE, ground cracking (GC), or POST for effective weed control [10]. Imazethapyr applied PPI or PRE controls many troublesome weeds such as coffee senna (Cassia occidentalis L.), common lambsquarters (Chenopodium album L.), morningglory species (Ipomoea spp.), pigweed species (Amaranthus spp.) including Palmer amaranth, prickly sida (Sida spinosa L.), purple and yellow nutsedge (Cyperus rotundus L. and C. esculentus L., respectively), spurred anoda [Anoda cristata (L.) Schlecht.], and wild poinsettia (Euphorbia heterophylla L.) $[29,36-39]$.

Imazethapyr applied POST provides broad spectrum and most consistent control when applied within 10 days of weed emergence [37,40,41]. Imazethapyr and imazapic are the only POST herbicides to effectively control both yellow and purple nutsedge $[29,42]$. Control is most effective when imazethapyr is applied to the soil or to yellow nutsedge that is no more than $12 \mathrm{~cm}$ tall $[10,42,43]$.

Imazapic is similar to imazethapyr and controls all the weeds controlled by imazethapyr [10,44-46]. In addition, imazapic provides control and suppression of Florida beggarweed [Desmodium tortuosum (S.W.) D.C.] and sicklepod [Senna obtusifolia (L.) Irwin \& Barneby), which are not adequately controlled by imazethapyr [47]. Imazethapyr provides consistent control of many broadleaf and sedge species if applied within 10 days after emergence, but imazapic has a longer effectiveness period when applied POST [10,42,46,48]. Imazapic also is effective for control of rhizome and seedling johnsongrass [Sorghum halepense (L.) Pers.], Texas millet, 
large crabgrass [Digitaria sanguinalis (L.) Scop.], southern crabgrass [Digitaria ciliaris (Retz.) Koel.], and broadleaf signalgrass [Brachiaria platyphylla (Griseb.) Nash] [46].

Peanut is susceptible to numerous fungal diseases caused by foliar and soilborne pathogens. Chlorothalonil has been the most widely used fungicide in the United States peanut production areas for control of early leaf spot caused by Cercospora arachidicola S. Hori, late leaf spot caused by Cercosporidium personatum Berk. \& M.A. Curtis, and rust caused by Puccinia arachidis Speg. for over 30 years $[49,50]$. Despite its widespread use across the peanut belt, chlorothalonil continues to provide effective control of foliar diseases [50,51]; however, it has no activity against any of the soilborne diseases such as southern stem rot caused by Sclerotium rolfsii Sacc. or Rhizoctonia pod or stem rot caused by Rhizoctonia solani Kühn $[49,52,53]$. Within the past 15 years, several fungicides, including the sterol biosynthesis inhibitor fungicide, tebuconazole, along with the strobilurin fungicides azoxystrobin and pyraclostrobin have been registered for use in peanut for control of both leaf spot and soilborne diseases [49,52-55].

Depending on the fungicide, the calendar spray regime in the southeastern United States may result in seven applications $[50,52]$ while in the southwest United States peanut growing region a maximum of five fungicide applications may be applied during the growing season [53,56]. Chlorothalonil is used to fill the remaining treatment slots in an azoxystrobin, pyraclostrobin, tebuconazole program to minimize the risk of fungal pathogens developing resistance to triazole or strobilurin fungicides [57].

Prothioconazole is a sterol biosynthesis inhibitor fungicide in the new triazolinthione class of fungicides [58] that has shown activity against the leaf spot pathogens, C. arachidicola and C. personatum, as well as the soilborne pathogens S. rolfsii and $R$. solani [59]. Prothioconazole has shown promise for control of cereal diseases in Europe when applied alone or in combination with strobilurin fungicides [58]. In addition, the activity of this fungicide on foliar diseases is of special interest because populations of both C. arachidicola and C. personatum have displayed reduced sensitivity to tebuconazole and noticeable reductions in efficacy of that fungicide [59]. Prothioconazole plus tebuconazole received registration for use in peanut during the 2008 growing season [60].

Management strategies to protect peanut from various weeds, insects, and fungi require multiple applications of herbicides, insecticides, or fungicides. Timing of application of herbicides and fungicides may coincide during the growing season, and co-application of these pesticides is desirable if herbicide or fungicide performance and peanut tolerance are not compromised [61]. Potential interactions related to physiological effects on plants and other organisms, application variables such as adjuvant, water quality, commercial formulation, and environmental stress can affect pesticide compatibility [61].

\section{Research needs}

Considerable research has been conducted over the past several years to define interactions among pesticides including interactions of herbicides in mixture with other herbicides and 
fungicides [62-65]. Peanut fungicides are applied beginning approximately 30 to 60 days after planting and can be applied until a few weeks prior to digging. Efficacy of clethodim and sethoxydim can be reduced by co-application with copper-containing fungicides or azoxystrobin, chlorothalonil, and pyraclostrobin $[8,66,67]$. Fluazinam and tebuconazole did not reduce grass control compared with graminicides applied alone $[8,9,66]$. Efficacy of herbicides that control dicotyledonous weeds and sedges are not generally affected by fungicides [66]. Weed species and size, and plant stress can affect the magnitude of interactions between herbicides and fungicides [66].

Additional research was conducted to define potential interactions of various postemergence herbicides and fungicides when used in combination on peanut for control of various broadleaf weeds and annual grasses. Therefore, the purpose of this research was to determine interactions of postemergence grass (clethodim and sethoxydim) and broadleaf herbicides (lactofen, imazethapyr, imazapic, aciflurofen, and 2,4-DB) with commonly used peanut fungicides (boscalid, fluazinam, pyraclostrobin, tebuconazole, or prothioconazole plus tebuconazole) for annual grass and broadleaf weed control in peanut as well as the response to foliar and soilborne disease development.

\section{Research methods with tank-mix combinations for weed and disease control}

\subsection{Weed control with tank-mix combinations}

Field studies were conducted in two different peanut growing regions of Texas from 2007 through 2010 to determine weed efficacy and peanut response to applications of herbicides and fungicides applied alone and in combination. Field studies at south Texas were conducted at the Texas A\&M AgriLife Research site near Yoakum and on the Texas Southern High Plains at Lamesa or Halfway. Soils at the Yoakum site were a Tremona loamy fine sand (thermic Aquic Arenic Paleustalfs) with less than 1\% organic matter and pH 7.0 to 7.2. The location near Lamesa was at the Agricultural Complex for Research and Extension Center (AG-CARES) on a Amarillo fine sandy loam (fine-loamy, mixed, superactive, thermic Aridic Paleustalf) with $0.4 \%$ organic matter and $\mathrm{pH}$ 7.8. The Halfway location was located west of Plainview at the Texas A\&M AgriLife Research and Extension Center on a Acuff clay loam (fine-loamy, mixed, thermic Aridic Paleustolls) with less than 1.0\% organic matter and pH 7.9.

The experimental design was a randomized complete block with a factorial arrangement of two grass or five broadleaf herbicides by three fungicides with three replications. All studies included a non-treated control. Each plot consisted of two rows spaced 97 or $101 \mathrm{~cm}$ apart and $7.6 \mathrm{~m}$ long.

\subsubsection{Weed efficacy studies}

Weed efficacy studies were divided into two groups: 1) a grass herbicide study and 2) a broadleaf weed study. The grass herbicide study included clethodim at $0.14 \mathrm{~kg}$ ai/ha or 
sethoxydim at $0.21 \mathrm{~kg}$ ai/ha while the broadleaf weed study included aciflurofen at $0.42 \mathrm{~kg}$ ai/ ha, imazapic at $0.07 \mathrm{~kg}$ ai/ha, imazethapyr at $0.07 \mathrm{~kg}$ ai/ha, lactofen at $0.22 \mathrm{~kg}$ ai/ha, or 2,4-DB at $0.42 \mathrm{~kg}$ ai/ha. Fungicides evaluated included pyraclostrobin at $0.27 \mathrm{~kg}$ ai $/ \mathrm{ha}$, tebuconazole at $0.23 \mathrm{~kg}$ ai $/$ ha, and the premix of prothioconazole at $0.084 \mathrm{~kg}$ ai $/$ ha plus tebuconazole at 0.168 $\mathrm{kg}$ ai/ha.

Herbicides and fungicides were applied alone and in combination to determine efficacy against various weeds. A crop oil concentrate (Agri-Dex, a blend of $83 \%$ paraffin-based petroleum oil and $17 \%$ surfactant) at $2.3 \mathrm{~L} /$ ha was added to each treatment except in 2007 at Yoakum where a non-ionic surfactant (X-77, 90\% nonionic surfactant) at $0.25 \% \mathrm{v} / \mathrm{v}$ was added. Herbicide and fungicides at Yoakum were applied with a $\mathrm{CO}_{2}$-pressurized backpack sprayer equipped with TeeJet 11002 DG flat fan spray tips (Spraying Systems Company, P.O. Box 7900, North Avenue, Wheaton, IL 60188) that delivered a spray volume of $190 \mathrm{~L} / \mathrm{ha}$ at $180 \mathrm{kPa}$ while on the Texas High Plains locations, fungicides and herbicides were applied with a $\mathrm{CO}_{2}$ pressurized backpack sprayer using TeeJet 110015 TT flat fan nozzles calibrated to deliver a spray volume of $94 \mathrm{~L} / \mathrm{ha}$ at $207 \mathrm{kPa}$. At Yoakum, the peanut variety Tamrun OL02 [68] was planted in each year at a seeding rate of $112 \mathrm{~kg} / \mathrm{ha}$. At the Texas High Plains locations, Flavor Runner 458 [69] was planted at the rate of $100 \mathrm{~kg} / \mathrm{ha}$.

Texas millet and southern crabgrass were present at Yoakum in 2007 and 2009 while broadleaf signalgrass was present in 2008. Texas millet was present at Lamesa in 2007. Palmer amaranth was present at Yoakum in 2007, 2008, and 2009, Lamesa in 2007, and Halfway in 2008 and 2009. Smellmelon (Cucumis melo L. var. Dudaim Naud.) was present at Yoakum in 2007, 2008, and 2009 while horse purslane (Trianthema portulacastrum L.) was present at Yoakum only in 2009. When present, all field plots were naturally infested with dense populations of Texas millet and broadleaf signalgrass at 4 to 6 plants $/ \mathrm{m}^{2}$, southern crabgrass at 6 to 8 plants $/ \mathrm{m}^{2}$, horse purslane at 6 to 8 plants $/ \mathrm{m}^{2}$, smellmelon at 6 to 8 plants $/ \mathrm{m}^{2}$, or Palmer amaranth at 4 to 6 plants/ $\mathrm{m}^{2}$. Typically, treatments were applied when annual grasses were 10 to $26 \mathrm{~cm}$ tall, Palmer amaranth was 15 to $30 \mathrm{~cm}$ tall, horse purslane was 10 to $20 \mathrm{~cm}$ tall, and smellmelon was 15 to $30 \mathrm{~cm}$ in length. No attempt was made to harvest peanut in the efficacy studies due to the difficulty in digging weedy plots $[10,13,17]$.

\subsubsection{Weed-free studies}

Studies also were conducted under weed-free conditions at the Lamesa and Halfway in 2008 and 2009. Plots were maintained weed-free with ethalfluralin (Sonalan HFP®, Dow AgroSciences, 9330 Zionsville Road, Indianapolis, IN 46268) at $0.84 \mathrm{~kg} / \mathrm{ha}$ applied preplant incorporated. At Lamesa, Flavor Runner 458 was planted in 2008 while Tamrun OL02 was planted in 2009; at Halfway, the Spanish market type, OLin [70] was planted both years of the study. Seeding rate for the runner market cultivars (Flavor Runner 458, Tamrun OL02) was $90 \mathrm{~kg} / \mathrm{ha}$ while OLin was planted at $100 \mathrm{~kg} / \mathrm{ha}$. Peanut phytotoxicity ratings were recorded throughout the growing season and peanut yield was obtained by digging each plot separately, air-drying in the field for 4 to 7 days, and harvesting pods from each plot with a combine. Weights were recorded after soil and trash were removed from plot samples were adjusted to $10 \%$ moisture. 
Weed control and peanut phytotoxicity, expressed as chlorosis and necrosis of leaf tissue, was visually estimated on a scale of 0 to 100 ( 0 indicating no weed kill or leaf chlorosis or necrosis and 100 indicating complete weed or peanut kill), relative to the non-treated control. Weed control was recorded approximately four weeks after POST herbicide applications while peanut phytotoxicity was recorded 5 to 14 days after herbicide application.

\subsubsection{Data analysis}

Weed control and peanut injury data were transformed to the arcsine square root prior to analysis of variance, but are expressed in their original form for clarity because the transformation did not alter interpretation. Visual estimates of weed control and peanut injury, and yield were subjected to analysis of variance to test effects of POST herbicide and fungicide. Means were compared with the appropriate Fisher's Protected LSD test at the 5\% probability level. The non-treated was not included in weed efficacy or peanut injury analysis but was included in peanut yield analysis.

\subsection{Disease control with tank-mix combinations}

Studies were conducted in two different peanut growing regions of Texas to determine disease control and peanut response to applications of herbicides and fungicides applied alone and in combination. Field studies at south Texas were conducted at the Texas A\&M AgriLife Research site near Yoakum while the central Texas studies were conducted at the Texas A\&M AgriLife Research and Extension Center near Stephenville. Soils at the Yoakum site were described previously. This site has been in continuous peanut for over forty years so there was a high concentration of soil-borne and foliar disease inoculum. The soil at the Stephenville site was a Windthorst loamy sand (fine mixed thermic Udic Paleustalfs) with less than $1 \%$ organic matter and $\mathrm{pH} 7.6$.

\subsubsection{Disease efficacy studies}

Studies in south Texas were conducted from 2008 to 2010 on early leaf spot and southern blight. These studies included the fungicides pyraclostrobin at $0.27 \mathrm{~kg}$ ai/ha, tebuconazole at $0.23 \mathrm{~kg}$ ai/ha, and the premix of prothioconazole at $0.084 \mathrm{~kg}$ ai/ha plus tebuconazole at $0.168 \mathrm{~kg}$ ai/ha and the herbicides aciflurofen at $0.42 \mathrm{~kg}$ ai/ha, clethodim at $0.14 \mathrm{~kg}$ ai/ha, imazapic at $0.07 \mathrm{~kg}$ ai/ha, imazethapyr at $0.07 \mathrm{~kg}$ ai/ha, lactofen at $0.22 \mathrm{~kg}$ ai/ha, sethoxydim at $0.21 \mathrm{~kg}$ ai/ha, or 2,4-DB at $0.42 \mathrm{~kg}$ ai/ha. Fungicides and herbicides were applied alone and in combination to determine efficacy against foliar and soilborne diseases. No adjuvant was included in these studies in 2008 or 2009; however, in 2010 a crop oil concentrate (Agri-Dex, a blend of 83\% paraffin-based petroleum oil and $17 \%$ surfactant) at $2.3 \mathrm{~L} /$ ha was added to each treatment.

Fungicides and herbicides alone and in combination were applied with a CO2-pressurized backpack sprayer equipped with three D2-23 hollow-cone spray nozzles per row in $140 \mathrm{~L}$ of water/ha at a pressure of $504 \mathrm{kPa}$. The experimental design was a randomized complete block with a factorial arrangement of seven herbicides by three fungicides. All studies included a non-treated control. Each plot consisted of four rows spaced $97 \mathrm{~cm}$ apart and $6.3 \mathrm{~m}$ long. The 
variety Tamrun OL02 [68] was planted in 2008 and 2009 while Florida 07 [71] was planted in 2010 at the rate of $112 \mathrm{~kg} / \mathrm{ha}$. Planting dates were June 16, 2008, July 1, 2009, and May 24, 2010.

Studies conducted in central Texas focused on early leaf spot and Sclerotinia blight caused by Sclerotina minor Jagger. These studies included the herbicides clethodim at $0.14 \mathrm{~kg}$ ai/ha and sethoxydim at $0.21 \mathrm{~kg}$ ai/ha and the fungicides boscalid at $0.49 \mathrm{~kg}$ ai $/ \mathrm{ha}$ and fluazinam at 0.88 $\mathrm{kg}$ ai/ha. Agridex at $1.0 \% \mathrm{v} / \mathrm{v}$ was included in all treatments. Each plot consisted of two rows spaced $91 \mathrm{~cm}$ apart and $7.9 \mathrm{~m}$ long. Fungicides and herbicides were applied alone and in combination with a CO2-pressurized backpack sprayer equipped with two 8002VS flat fan spray nozzles per row in $140 \mathrm{~L}$ of water/ha at a pressure of $134 \mathrm{kPa}$. The runner-type variety Flavor Runner 458 [69] was planted each year of the study at $95 \mathrm{~kg} / \mathrm{ha}$.

Typical peanut injury resulted in rapid damage to plant tissue after application and manifested as small necrotic lesions. The visible injury on leaflets with 2,4-DB was common and consisted of typical 2,4-DB damage which consisted of elongated leaflets with a slightly faded appearance [10]. This symptomology was not visible on new growth and remained visible on lower leaves throughout the growing season. Peanut phytotoxicity ratings were recorded 7 days after treatment at Yoakum. Peanut injury was estimated visually on a scale of 0 to 100 ( 0 indicating no leaf chlorosis or necrosis and 100 indicating complete peanut kill), relative to the non-treated control. Severity of leaf spot was rated in the center two rows using the Florida leaf spot scoring system where 1 = no leaf spot, and 10 = plants completely defoliated and dead because of leaf spot $[49,59]$. Values of 1 through 4 on the scale reflect increasing incidence of leaflets with spots, and occurrence of spots in lower versus upper canopy of the plots; whereas values 4 through 10 reflect increasing levels of defoliation [51]. The leaf spot rating was recorded immediately prior to peanut digging.

Loci of southern stem rot or Sclerotinia blight (where applicable) were counted immediately after peanut plants were inverted. A locus represented $31 \mathrm{~cm}$ or less of linear row with one or more plants infected with S. rolfsii or S. minor [72]. Plots were harvested in south Texas in 2008 and 2010, but not in 2009 due to extremely wet conditions which persisted during late October and November and prevented digging of individual plots (Table 1). Plots were harvested in 2008 and 2009 in central Texas.

All test areas were maintained weed-free with a preemergence tank-mix application of pendimethalin at $1.06 \mathrm{~kg}$ ai/ha plus $S$-metolachlor at $1.42 \mathrm{~kg}$ ai/ha. Overhead sprinkler irrigation was applied on a 1- to 2-week schedule throughout the growing season as needed.

\subsubsection{Data analysis}

Peanut yields were obtained by digging each plot separately, air-drying in the field for 4 to 7 days, and harvesting pods from each plot with a combine. Weights were recorded after soil and trash were removed from plot samples were adjusted to $10 \%$ moisture. Leaf spot ratings and incidence of soilborne disease development were used for comparison of tank-mix combinations. Data were analyzed using PROC GLM with SAS (SAS Institute, Inc., Cary, NC) and a model statement appropriate for a factorial design. Treatments means were separated by Fisher's protected least significant difference test at $\mathrm{P} \leq 0.05$. 


\section{Effects of tank mix combinations on weed control, peanut phytotoxicity, and peanut yield}

\subsection{Weed efficacy with combinations of herbicides plus fungicides.}

There was no herbicide by fungicide by year interaction for Texas millet, southern crabgrass, or broadleaf signalgrass control; therefore, that data are combined over clethodim and sethoxydim herbicides.

\subsubsection{Annual grass control}

No differences in broadleaf signalgrass, Texas millet, or southern crabgrass control were noted between clethodim or sethoxydim when applied alone or in combination with any of the fungicides (Table 2). Grichar [73] reported that clethodim and sethoxydim controlled 3 to 10 $\mathrm{cm}$ tall Texas millet and southern crabgrass at least $85 \%$. Clethodim applied to 15 to $25 \mathrm{~cm}$ tall Texas millet or southern crabgrass provided no better than $89 \%$ Texas millet control while southern crabgrass control varied from 51 to $95 \%$ [73]. Sethoxydim applied to the same height Texas millet or southern crabgrass controlled Texas millet 79 to $87 \%$ and southern crabgrass control was no better than $76 \%$ [73].

\begin{tabular}{|c|c|c|c|c|}
\hline Herbicide & Rate & $\begin{array}{l}\text { Texasc }^{c} \\
\text { millet }\end{array}$ & $\begin{array}{l}\text { Southern } \\
\text { crabgrass }\end{array}$ & $\begin{array}{c}\text { Broadleaf } \\
\text { signalgrass }\end{array}$ \\
\hline & kg ai/ha & & $\%$ & \\
\hline Clethodim & 0.14 & 96 & 96 & 98 \\
\hline Sethoxydim & 0.21 & 95 & 96 & 98 \\
\hline LSD (0.05) & & $\mathrm{NS}^{\mathrm{d}}$ & NS & NS \\
\hline \multicolumn{5}{|c|}{$\begin{array}{l}\text { a Herbicides and rates included clethodim at } 0.14 \mathrm{~kg} \text { ai/ha and sethoxydim at } 0.21 \mathrm{~kg} \text { ai/ha. Fungicides and rates included } \\
\text { pyraclostrobin at } 0.27 \mathrm{~kg} \text { ai/ha, tebuconazole at } 0.23 \mathrm{~kg} \text { ai/ha, and the premix of prothioconazole at } 0.084 \mathrm{~kg} \text { ai/ha }+ \\
\text { tebuconazole at } 0.168 \mathrm{~kg} \text { ai/ha. Data were combined over fungicides due to a lack of interaction. } \\
\text { b Texas millet present in south Texas in } 2007 \text { and } 2009 \text { and at Lamesa in } 2007 \text {. Southern crabgrass present in south } \\
\text { Texas in } 2007 \text { and } 2009 \text {. Broadleaf signalgrass present in south Texas in } 2008 \text {. } \\
\text { c Texas millet, Urochloa texana (Buckley) R. D. Webster; Southern crabgrass, Digitaria ciliaris (Retz.) Koeler; broadleaf } \\
\text { signalgrass, Brachiaria platyphylla (Griseb.) Nash. } \\
\text { d NS, not significant at the } 5 \% \text { level of probability. }\end{array}$} \\
\hline
\end{tabular}

Table 2. Annual grass control with clethodim and sethoxydim., ${ }^{a, b}$

Lancaster et al. [8,9] reported large crabgrass control was reduced with clethodim when applied with pyraclostrobin, chlorothalonil, and azoxystrobin; however, fluazinam, propiconazole plus trifloxystrobin, and tebuconazole did not reduce large crabgrass control by clethodim. Similarly, Jordan et al. [66] reported that azoxystrobin and chlorothalonil, but not tebuconazole, reduced annual grass control by clethodim. Also Lancaster et al. [8,9] reported 
that large crabgrass control was reduced when sethoxydim was applied with azoxystrobin or pyraclostrobin, but not fluazinam, propiconazole plus trifloxystrobin, or tebuconazole.

\subsubsection{Palmer amaranth control}

At Yoakum in 2007 and 2008 and Halfway in 2008 there was an herbicide by fungicide interaction; therefore, those data are presented as a 2-way interaction of broadleaf herbicide by fungicide (Table 3). However, only herbicide effects were significant at Lamesa in 2007 and Halfway and Yoakum in 2009 (Table 4).

In 2007 at Yoakum, lactofen, aciflurofen, and imazapic alone controlled Palmer amaranth at least $91 \%$ while 2,4-DB and imazethapyr alone provided $83 \%$ and $68 \%$ control, respectively (Table 3). Lactofen plus tebuconazole and aciflurofen plus either the premix of prothioconazole plus tebuconazole or tebuconazole reduced Palmer amaranth control over each respective herbicide applied alone. In 2008 at Yoakum, all herbicides alone controlled Palmer amaranth at least $92 \%$. Reduced control from each respective herbicide alone was noted with acifluorfen plus either pyraclostrobin or tebuconazole and imazethapyr or 2,4-DB plus pyraclostrobin. At the Halfway location, lactofen and aciflurofen alone provided poor control $(\leq 25 \%)$ of Palmer amaranth while imazethapyr, imazapic, and 2,4-DB controlled Palmer amaranth at least 77\% (Table 3). Only the combination of 2,4-DB plus the premix of prothioconazole plus tebuconazole reduced control when compared to 2,4-DB alone.

At Lamesa, all herbicides controlled Palmer amaranth less than $60 \%$ while at Yoakum there was no difference in Palmer amaranth control following all herbicide treatments (Table 4). At the Halfway location, lactofen, imazapic, and imazethapyr controlled Palmer amaranth at least $98 \%$ while 2,4-DB and aciflurofen controlled this weed $75 \%$ and $54 \%$, respectively.

Grichar [74] reported that imazapic at 0.04 to $0.07 \mathrm{~kg} / \mathrm{ha}$ controlled Palmer amaranth at least $95 \%$ when applied to weeds that were less than $15 \mathrm{~cm}$ tall while imazethapyr provided at least $90 \%$ control in 2 of 3 years. In other research, Jordan et al. [66] reported that smooth pigweed (A. hybridus L.) control by imazethapyr was reduced by tank mixing with fungicides.

\subsubsection{Horse purslane control}

There was an herbicide by fungicide interaction for horse purslane in 2009. Lactofen and 2,4$\mathrm{DB}$ alone and in combination with fungicides provided almost complete control of horse purslane (Table 3). Aciflurofen alone controlled $97 \%$ horse purslane while antagonism was noted with acifluorfen plus the premix of prothioconazole plus tebuconazole combinations. All imazethapyr plus fungicide combinations reduced horse purslane control compared to imazethapyr alone. Imazapic alone or in combination failed to control horse purslane.

Horse purslane can be a stronger competitor with peanut early in the growing season than common purslane due to a more upright growth than that of common purslane [75]. Grichar [75] reported that aciflurofen and lactofen alone or combinations of these herbicides with 2,4DB controlled horse purslane at least $70 \%$ when evaluated 21 days after treatment (DAT), but no greater than $75 \%$ control was observed when rated up to 115 DAT. In later work, Grichar 


\begin{tabular}{|c|c|c|c|c|c|}
\hline & & \multicolumn{3}{|c|}{ Palmer amaranth } & \multirow{3}{*}{$\begin{array}{c}\begin{array}{c}\text { Horse } \\
\text { purslane }\end{array} \\
\text { Yoakum }\end{array}$} \\
\hline & & \multirow{2}{*}{$\frac{2007}{\text { Yoakum }}$} & \multicolumn{2}{|c|}{2008} & \\
\hline & & & Yoakum & Halfway & \\
\hline Herbicide & Fungicide & & & & \\
\hline Lactofen & - & 93 & 92 & 22 & 100 \\
\hline Lactofen & Pyraclostrobin & 100 & 100 & 18 & 100 \\
\hline Lactofen & $\begin{array}{c}\text { Prothioconazole + } \\
\text { tebuconazole }\end{array}$ & 78 & 93 & 17 & 100 \\
\hline Lactofen & Tebuconazole & 70 & 93 & 17 & 99 \\
\hline Acifluorfen & - & 91 & 97 & 25 & 97 \\
\hline Acifluorfen & Pyraclostrobin & 73 & 80 & 18 & 80 \\
\hline Acifluorfen & $\begin{array}{l}\text { Prothioconazole } \\
\text { + tebuconazole }\end{array}$ & 57 & 97 & 30 & 58 \\
\hline Acifluorfen & Tebuconazole & 60 & 85 & 18 & 99 \\
\hline Imazethapyr & - & 68 & 100 & 77 & 80 \\
\hline \multirow[t]{2}{*}{ Imazethapyr } & Pyraclostrobin & 88 & 86 & 75 & 0 \\
\hline & Prothioconazole & & 98 & & \\
\hline Imazethapyr & $\begin{array}{l}\text { Prothioconazole } \\
\text { + tebuconazole }\end{array}$ & 82 & 98 & 82 & 25 \\
\hline Imazethapyr & Tebuconazole & 87 & 93 & 80 & 10 \\
\hline Imazapic & - & 94 & 97 & 96 & 13 \\
\hline Imazapic & Pyraclostrobin & 94 & 99 & 94 & 0 \\
\hline Imazapic & $\begin{array}{l}\text { Prothioconazole } \\
\text { + tebuconazole }\end{array}$ & 86 & 99 & 94 & 7 \\
\hline Imazapic & Tebuconazole & 97 & 93 & 94 & 0 \\
\hline $2,4-D B$ & - & 83 & 96 & 88 & 100 \\
\hline $2,4-D B$ & Pyraclostrobin & 67 & 87 & 87 & 100 \\
\hline 2,4-DB & $\begin{array}{l}\text { Prothioconazole } \\
+ \text { tebuconazole }\end{array}$ & 98 & 100 & 28 & 100 \\
\hline $2,4-D B$ & Tebuconazole & 100 & 97 & 83 & 99 \\
\hline LSD (0.05) & & 20 & 9 & 18 & 32 \\
\hline
\end{tabular}

a Agri-Dex at $2.3 \mathrm{~L} / \mathrm{h}$ a was added to each treatment except in 2007 at Yoakum where $\mathrm{X}-77$ at $0.25 \% \mathrm{v} / \mathrm{v}$ was added. b Herbicides and rates included aciflurofen at $0.42 \mathrm{~kg}$ ai $/$ ha, imazapic at $0.07 \mathrm{~kg}$ ai/ha, imazethapyr at $0.07 \mathrm{~kg}$ ai $/ \mathrm{ha}$, lactofen at $0.22 \mathrm{~kg}$ ai/ha, or 2,4-DB at $0.42 \mathrm{~kg}$ ai/ha. Fungicides and rates included pyraclostrobin at $0.27 \mathrm{~kg}$ ai/ha, tebuconazole at $0.23 \mathrm{~kg}$ ai $/ \mathrm{ha}$, and the premix of prothioconazole at $0.084 \mathrm{~kg}$ ai $/ \mathrm{ha}+$ tebuconazole at $0.168 \mathrm{~kg}$ ai $/ \mathrm{ha}$.

c Palmer amaranth, Amaranthus palmeri S. Wats.; horse purslane, Trianthema portulacastrum L.

d Present only in 2009.

Table 3. Palmer amaranth and horse purslane control with herbicide-fungicide combinations. a,b

[76] reported that in one year, lactofen applied to horse purslane less than $15 \mathrm{~cm}$ tall controlled this weed $93 \%$ while in another year, lactofen applied to horse purslane less than $15 \mathrm{~cm}$ tall or 20 to $30 \mathrm{~cm}$ tall provided at least 93\% control while acifluorfen applied to horse purslane less than $15 \mathrm{~cm}$ tall controlled this weed $77 \%$. 


\subsubsection{Smellmelon control}

Only herbicides were significant for smellmelon control (Table 4). No difference in smellmelon control was noted with any herbicides in 2007, while in 2008 imazethapyr produced the worst control. In 2009, lactofen controlled less smellmelon than imazapic. Grichar [76] reported that imazapic provided the most consistent control of smellmelon while acifluorfen, imazethapyr, imazapic, and lactofen controlled at least $80 \%$ smellmelon in some years but in other years control was less than $70 \%$. Imazapic at 0.04 to $0.07 \mathrm{~kg} /$ ha controlled smellmelon greater than $90 \%$ in corn (Zea mays L.) regardless whether applied PRE, early POST, or late POST [77]. Grichar [78] reported that imazapic provided consistent control (> 85\%) of citronmelon (Citrullus lanatus var. citroides) in peanut. Typically, season-long smellmelon control with 2,4DB is poor. This can be attributed to lack of any residual activity of 2,4-DB and continued germination of seed and smellmelon growth [76].

\subsubsection{Peanut phytotoxicity with tank mix combinations}

\subsubsection{Clethodim/sethoxydim plus fungicide combinations}

No peanut phytotoxicity was noted with any graminicide by fungicide combinations at Yoakum or Halfway (data not shown); however, at Lamesa there was a treatment by year interaction.

\begin{tabular}{|c|c|c|c|c|c|c|}
\hline & \multicolumn{3}{|c|}{ Palmer amaranth ${ }^{c}$} & \multicolumn{3}{|c|}{ Smellmelon } \\
\hline & Lamesa & Yoakum & Halfway & 2007 & 2008 & 2009 \\
\hline & \multicolumn{6}{|c|}{$\%$} \\
\hline Lactofen & 49 & 94 & 98 & 93 & 99 & 89 \\
\hline Aciflurofen & 38 & 90 & 54 & 88 & 99 & 96 \\
\hline Imazethapyr & 28 & 88 & 99 & 88 & 91 & 95 \\
\hline Imazapic & 25 & 90 & 98 & 99 & 98 & 98 \\
\hline $2,4-D B$ & 59 & 96 & 75 & 93 & 99 & 96 \\
\hline LSD (0.05) & 6 & $N S^{d}$ & 12 & NS & 4 & 9 \\
\hline \multicolumn{7}{|c|}{$\begin{array}{l}\text { a Data are pooled over herbicides due to a lack of interaction. Herbicides and rates included aciflurofen at } 0.42 \mathrm{~kg} \text { ai/ha, } \\
\text { imazapic at } 0.07 \mathrm{~kg} \text { ai/ha, imazethapyr at } 0.07 \mathrm{~kg} \text { ai } / \text { ha, lactofen at } 0.22 \mathrm{~kg} \text { ai } / \mathrm{ha} \text {, or } 2,4-\mathrm{DB} \text { at } 0.42 \mathrm{~kg} \text { ai/ha. Fungicides } \\
\text { and rates included pyraclostrobin at } 0.27 \mathrm{~kg} \text { ai } / \mathrm{ha} \text {, tebuconazole at } 0.23 \mathrm{~kg} \text { ai } / \mathrm{ha} \text {, and the premix of prothioconazole at } \\
0.084 \mathrm{~kg} \text { ai/ha + tebuconazole at } 0.168 \mathrm{~kg} \text { ai } / \mathrm{ha} \text {. } \\
\text { b Palmer amaranth present at Lamesa in } 2007 \text {, Yoakum in } 2009 \text {, and Halfway in } 2009 \text {. } \\
\text { c Palmer amaranth, Amaranthus palmeri S. Wats.; smellmelon, Cucumis melo L. var. Dudaim Naud. } \\
\text { d NS, not significant at the } 5 \% \text { level of probability. }\end{array}$} \\
\hline
\end{tabular}

Table 4. Weed control with various postemergence herbicides. ${ }^{a, b}$

In 2007 (with Texas millet pressure) and in 2009 (weed-free), peanut phytotoxicity (up to 12\%) was evident with clethodim and sethoxydim combinations with either pyraclostrobin, tebuconazole, and the premix of prothioconazole + tebuconazole up to two weeks after 
application (Table 5). In 2007, clethodim, sethoxydim, or tebuconazole alone or clethodim or sethoxydim in combination with tebuconazole caused no phytotoxicity. All other combinations resulted in at least 3\% phytotoxicity. Either graminicide in combination with prothioconazole plus tebuconazole or prothioconazole plus tebuconazole alone caused the greatest phytotoxicity. In 2009, similar results were noted; however, pyraclostrobin alone or in combination with either graminicide caused the greatest injury (Table 5). Subsequent new growth did not exhibit adverse effects of any tank-mix combination and was $2 \%$ or less, four weeks after application (data not shown).

\begin{tabular}{|c|c|c|c|}
\hline Herbicide & Fungicide & 2007 & 2009 \\
\hline & & \multicolumn{2}{|c|}{$\%$} \\
\hline Clethodim & - & 2 & 0 \\
\hline Clethodim & Pyraclostrobin & 3 & 13 \\
\hline Clethodim & Tebuconazole & 0 & 0 \\
\hline Clethodim & $\begin{array}{l}\text { Prothioconazole } \\
+ \text { tebuconazole }\end{array}$ & 10 & 8 \\
\hline Sethoxydim & - & 2 & 0 \\
\hline Sethoxydim & Pyraclostrobin & 5 & 12 \\
\hline Sethoxydim & Tebuconazole & 0 & 0 \\
\hline Sethoxydim & $\begin{array}{l}\text { Prothioconazole } \\
+ \text { tebuconazole }\end{array}$ & 12 & 3 \\
\hline - & Pyraclostrobin & 4 & 11 \\
\hline- & Tebuconazole & 0 & 0 \\
\hline- & $\begin{array}{l}\text { Prothioconazole } \\
+ \text { tebuconazole }\end{array}$ & 8 & 0 \\
\hline LSD (0.05) & & 3 & 3 \\
\hline $\begin{array}{l}\text { Herbicides and rates incl } \\
\text { pyraclostrobin at } 0.27 \mathrm{~kg} \\
\text { tebuconazole at } 0.168 \mathrm{~kg}\end{array}$ & $\begin{array}{l}4 \mathrm{~kg} \text { ai/ha and set } \\
\text { at } 0.23 \mathrm{~kg} \text { ai } / \mathrm{ha} \text {, c }\end{array}$ & $\begin{array}{l}\text { gai/ha. } \\
\text { prothio }\end{array}$ & $\begin{array}{l}\text { d rates } \\
.084 \mathrm{~kg}\end{array}$ \\
\hline
\end{tabular}

Table 5. Peanut phytotoxicity with graminicide plus fungicide combinations at Lamesa in 2007 and 2009. ${ }^{\text {a }}$

\subsubsection{Aciflurofen, imazapic, imazethapyr, lactofen, or 2,4-DB plus fungicide combinations}

Phytotoxicity observations were not recorded in the weed efficacy studies with the exception of Yoakum in 2008; however, phytotoxicity ratings were recorded in the weed-free studies conducted at Lemasa in 2008 and 2009 and Halfway in 2009. In these studies, there was a significant herbicide by fungicide interaction; therefore, data are presented separately by location. Phytotoxicity varied across locations and treatments but in most instances was greater with the use of aciflurofen or lactofen. 
In 2008 at Yoakum, lactofen alone and in combination with prothioconazole plus tebuconazole or tebuconazole alone caused at least $10 \%$ peanut phytotoxicity while aciflurofen alone or in combination with any of the fungicides caused 4 to $7 \%$ phytotoxicity. At Lamesa, combinations with aciflurofen, lactofen, and 2,4-DB caused the greatest injury (Table 6). Imazethapyr or imazapic alone or in combination with pyraclostrobin resulted in no injury. Imazethapyr plus tebuconazole caused no injury while imazapic plus tebuconazole resulted in $10 \%$ injury.

In 2009 at Lamesa, imazapic, imazethapyr, and 2,4-DB alone resulted in no injury; however, imazapic plus either pyraclostrobin or prothioconazole plus tebuconazole, imazapic plus pyraclostrobin, and 2,4-DB plus any fungicide resulted in 5 to 15\% phytotoxicity (Table 6). Slight peanut phytotoxicity was also noted with the fungicides pyraclostrobin and tebuconazole. At Halfway, peanut injury with aciflurofen or lactofen was greater than at Lamesa with the exception of lactofen plus pyraclostrobin which caused 9 to $10 \%$ injury at both locations (Table 6).

\subsubsection{Peanut yield as influenced by tank mix combinations}

Under weed-free conditions, when using either the grass or broadleaf herbicides with fungicides, no negative response with respect to peanut yield was noted when compared with the non-treated control for either runner or Spanish market types (data not shown). Most studies conducted on herbicide-fungicide interactions on peanut have focused on either weed efficacy or disease control and few have reported on effect on peanut yield. No studies could be found that reported any peanut yield reductions with clethodim or sethoxydim under weedfree conditions. Although lactofen at $0.22 \mathrm{~kg} / \mathrm{ha}$ caused peanut leaf bronzing and spotting [74], lactofen produced a similar yield when compared to the untreated, weed-free control [79]. Richburg et al. [80] reported no yield differences with runner, Spanish, or Virginia peanut cultivars with imazethapyr at $0.07 \mathrm{~kg} / \mathrm{ha}$ in Georgia or Texas. No reduction in peanut grade or yield following imazapic treatments have been observed in several studies [76,81,82]. Grichar et al. [83] reported that single and multiple applications of 2,4-DB at $0.45 \mathrm{~kg} / \mathrm{ha}$ did not affect runner-type yield.

\begin{tabular}{|c|c|c|c|c|c|}
\hline & & \multicolumn{4}{|c|}{ Phytotoxictyc } \\
\hline & & \multicolumn{2}{|c|}{2008} & \multicolumn{2}{|c|}{2009} \\
\hline & & Yoakum & Lamesa & Lamesa & Halfway \\
\hline Herbicide & Fungicide & \multicolumn{4}{|c|}{$\%$} \\
\hline - & - & 0 & 0 & 0 & 0 \\
\hline Lactofen & - & 10 & 10 & 13 & 23 \\
\hline Lactofen & Pyraclostrobin & 2 & 4 & 9 & 10 \\
\hline Lactofen & $\begin{array}{l}\text { Prothioconazole + } \\
\text { tebuconazole }\end{array}$ & 12 & 10 & 8 & 22 \\
\hline
\end{tabular}




\section{Phytotoxicty}

\begin{tabular}{|c|c|c|c|c|c|}
\hline & & \multicolumn{2}{|c|}{2008} & \multicolumn{2}{|c|}{2009} \\
\hline & & Yoakum & Lamesa & Lamesa & Halfway \\
\hline Lactofen & Tebuconazole & 12 & 12 & 7 & 25 \\
\hline Acifluorfen & - & 5 & 5 & 5 & 20 \\
\hline Acifluorfen & Pyraclostrobin & 4 & 5 & 5 & 17 \\
\hline Acifluorfen & $\begin{array}{l}\text { Prothioconazole } \\
\text { + tebuconazole }\end{array}$ & 7 & 9 & 5 & 23 \\
\hline Acifluorfen & Tebuconazole & 6 & 9 & 5 & 22 \\
\hline Imazethapyr & - & 0 & 0 & 0 & 0 \\
\hline Imazethapyr & Pyraclostrobin & 2 & 0 & 7 & 0 \\
\hline Imazethapyr & $\begin{array}{l}\text { Prothioconazole } \\
+ \text { tebuconazole }\end{array}$ & 0 & 4 & 5 & 12 \\
\hline Imazethapyr & Tebuconazole & 0 & 0 & 0 & 0 \\
\hline Imazapic & - & 0 & 0 & 0 & 0 \\
\hline Imazapic & Pyraclostrobin & 0 & 0 & 8 & 0 \\
\hline Imazapic & $\begin{array}{l}\text { Prothioconazole } \\
\text { + tebuconazole }\end{array}$ & 0 & 10 & 0 & 3 \\
\hline Imazapic & Tebuconazole & 0 & 10 & 0 & 3 \\
\hline $2,4-D B$ & - & 0 & 5 & 0 & 10 \\
\hline 2,4-DB & Pyraclostrobin & 3 & 12 & 15 & 18 \\
\hline $2,4-D B$ & $\begin{array}{l}\text { Prothioconazole } \\
+ \text { tebuconazole }\end{array}$ & 1 & 12 & 10 & 20 \\
\hline $2,4-D B$ & Tebuconazole & 0 & 6 & 5 & 5 \\
\hline - & Pyraclostrobin & 0 & 0 & 10 & 3 \\
\hline- & $\begin{array}{l}\text { Prothioconazole } \\
\text { + tebuconazole }\end{array}$ & 0 & 1 & 0 & 13 \\
\hline - & Tebuconazole & 0 & 0 & 5 & 0 \\
\hline LSD (0.05) & & 3 & 1 & 2 & 5 \\
\hline
\end{tabular}

a Agri-Dex at $2.3 \mathrm{~L} / \mathrm{h}$ a was added to each treatment.

b Herbicides and rates included aciflurofen at $0.42 \mathrm{~kg}$ ai/ha, imazapic at $0.07 \mathrm{~kg}$ ai/ha, imazethapyr at $0.07 \mathrm{~kg}$ ai/ha, lactofen at $0.22 \mathrm{~kg}$ ai $/ \mathrm{ha}$, or 2,4-DB at $0.42 \mathrm{~kg}$ ai/ha. Fungicides and rates included pyraclostrobin at $0.27 \mathrm{~kg}$ ai $/ \mathrm{ha}$, tebuconazole at $0.23 \mathrm{~kg}$ ai $/ \mathrm{ha}$, and the premix of prothioconazole at $0.084 \mathrm{~kg}$ ai $/ \mathrm{ha}$ + tebuconazole at $0.168 \mathrm{~kg}$ ai $/ \mathrm{ha}$. ' Rating index: $0=$ no leaf chlorosis or necrosis, $100=$ plants completely dead.

Table 6. Peanut phytotoxicity with herbicide-fungicide combinations when rated 12 to 15 days after treatment.a,b 


\section{Effects of tank mix combinations on foliar and soilborne disease control, peanut phytotoxicity, and peanut yield}

\subsection{Disease control with tank mix combinations}

Rainfall in south Texas was below average in 2008 and the early to mid-part of the 2009 peanut growing season (May through August); however, rainfall amounts were above average for the latter portion of the 2009 season (September through November). Rainfall amounts for 2010 were above average for May, July, August, and September (Table 7). In central Texas, rainfall amounts in 2008 were below average for all months (May through November) with the exception of July which was slightly above average while in 2009 rainfall was below average for all months with the exception of July and October (Table 7).

\begin{tabular}{|c|c|c|c|c|c|c|c|}
\hline \multirow[b]{2}{*}{ Month } & \multicolumn{4}{|c|}{ South Texas } & \multicolumn{3}{|c|}{ Central Texas } \\
\hline & 2008 & 2009 & 2010 & $60-y r$ avg & 2008 & 2009 & 30-yr avg \\
\hline & \multicolumn{7}{|c|}{$\mathrm{mm}$} \\
\hline May & 1.3 & 16.3 & 118.4 & 112.2 & 76.5 & 65.5 & 117.6 \\
\hline June & 65.3 & 3.8 & 95.0 & 109.2 & 30.5 & 8.6 & 100.0 \\
\hline July & 54.9 & 5.3 & 200.7 & 65.8 & 47.2 & 79.0 & 34.7 \\
\hline August & 57.9 & 42.7 & 89.4 & 78.7 & 50.3 & 2.0 & 58.3 \\
\hline September & 2.5 & 114.0 & 223.3 & 102.6 & 55.9 & 10.6 & 70.5 \\
\hline October & 14.2 & 352.6 & 0 & 94.5 & 32.5 & 127.3 & 72.3 \\
\hline November & 25.9 & 111.3 & 71.1 & 75.4 & 40.4 & 25.9 & 54.5 \\
\hline Total & 222.0 & 646.0 & 797.9 & 638.4 & 333.3 & 318.9 & 507.9 \\
\hline
\end{tabular}

Table 7. Rainfall amounts in south Texas and central Texas from 2008 through 2010

\subsubsection{Early leaf spot control in South Texas}

There was an herbicide by fungicide interaction for early leaf spot control in 2008 and 2009. In 2010, the main plots of herbicide and fungicide were significant for early leaf spot control; therefore, that data were averaged over herbicides and fungicides only. Foliar disease development was moderate in 2008 due to extreme drought and hot conditions that persisted throughout the 2008 and the early portion of the 2009 growing seasons. Typically, early leaf spot epidemics are favored by temperatures of approximately 16 to $250 \mathrm{C}$ and long periods of high relative humidity are required for infections to occur [84]. All herbicides alone, with the exception of sethoxydim and lactofen, were not different from the non-treated control with respect to early leaf spot development in 2008 (Table 8). All fungicides alone or in combination with any of the herbicides produced leaf spot levels that were less than the non-treated control. When individual fungicides were compared with the respective fungicide plus herbicide 
treatments some differences were noted. Pyraclostrobin alone resulted in less early leaf spot than pyraclostrobin plus either imazapic, lactofen, or sethoxydim. No differences were noted between tebuconazole alone or in combination with any herbicide. Prothioconazole plus tebuconazole alone resulted in less early leaf spot than prothioconazole plus tebuconazole in combination with acifluorfen (Table 8).

\begin{tabular}{|c|c|c|c|c|c|c|c|}
\hline \multirow[b]{2}{*}{ Fungicide } & \multirow[b]{2}{*}{ Herbicide } & \multicolumn{2}{|c|}{ Leaf spot ${ }^{b}$} & \multirow{2}{*}{$\begin{array}{c}\begin{array}{c}\text { Southern } \\
\text { blight }^{c}\end{array} \\
2010\end{array}$} & \multicolumn{2}{|c|}{ Phytotoxicity ${ }^{d}$} & \multirow{2}{*}{$\begin{array}{r}\text { Yield } \\
2008\end{array}$} \\
\hline & & 2008 & 2009 & & 2009 & 2010 & \\
\hline & & \multicolumn{2}{|c|}{ Florida scale } & $\%$ Incidence & \multicolumn{2}{|c|}{$\%$} & $\mathrm{~kg} / \mathrm{ha}$ \\
\hline- & - & 6.8 & 9.4 & 37 & 0 & 0 & 1860 \\
\hline- & Clethodim & 6.3 & 9.3 & 24 & 0 & 0 & 1680 \\
\hline- & Sethoxydim & 5.7 & 9.3 & 89 & 0 & 0 & 1510 \\
\hline- & Lactofen & 5.5 & 9.6 & 45 & 11 & 11 & 1860 \\
\hline- & Aciflurofen & 6.9 & 9.4 & 61 & 5 & 7 & 2320 \\
\hline- & Imazethapyr & 6.0 & 9.3 & 69 & 0 & 0 & 1500 \\
\hline- & Imazapic & 6.3 & 9.2 & 50 & 0 & 0 & 1810 \\
\hline- & $2,4-D B$ & 7.0 & 9.2 & 21 & 0 & 3 & 1550 \\
\hline Pyraclostrobin & - & 2.5 & 5.6 & 29 & 0 & 6 & 2670 \\
\hline Pyraclostrobin & Clethodim & 3.0 & 5.7 & 21 & 0 & 8 & 2470 \\
\hline Pyraclostrobin & Sethoxydim & 3.5 & 5.8 & 27 & 0 & 10 & 1630 \\
\hline Pyraclostrobin & Lactofen & 3.5 & 5.8 & 13 & 4 & 7 & 2440 \\
\hline Pyraclostrobin & Acifluorfen & 3.2 & 5.9 & 21 & 1 & 7 & 1830 \\
\hline Pyraclostrobin & Imazethapyr & 3.0 & 5.6 & 29 & 0 & 8 & 1550 \\
\hline Pyraclostrobin & Imazapic & 3.8 & 6.6 & 18 & 0 & 7 & 2060 \\
\hline Pyraclostrobin & $2,4-D B$ & 3.0 & 5.7 & 17 & 1 & 10 & 1560 \\
\hline Tebuconazole & - & 3.7 & 7.0 & 10 & 0 & 0 & 1780 \\
\hline Tebuconazole & Clethodim & 4.0 & 7.8 & 24 & 0 & 0 & 1870 \\
\hline Tebuconazole & Sethoxydim & 4.0 & 7.2 & 24 & 0 & 0 & 1970 \\
\hline Tebuconazole & Lactofen & 4.5 & 6.3 & 19 & 8 & 8 & 1890 \\
\hline Tebuconazole & Acifluorfen & 4.0 & 8.4 & 27 & 4 & 8 & 1720 \\
\hline Tebuconazole & Imazethapyr & 4.0 & 7.2 & 35 & 0 & 0 & 1970 \\
\hline Tebuconazole & Imazapic & 3.3 & 7.7 & 10 & 0 & 0 & 1450 \\
\hline Tebuconazole & $2,4-D B$ & 4.0 & 7.1 & 21 & 0 & 4 & 2670 \\
\hline Prothioconazole & - & 3.0 & 6.8 & 37 & 0 & 0 & 2080 \\
\hline
\end{tabular}




\begin{tabular}{|c|c|c|c|c|c|c|c|}
\hline \multirow[b]{2}{*}{ Fungicide } & \multirow[b]{2}{*}{ Herbicide } & \multicolumn{2}{|c|}{ Leaf spot ${ }^{b}$} & \multirow{2}{*}{$\begin{array}{c}\begin{array}{c}\text { Southern } \\
\text { blight }\end{array} \\
2010\end{array}$} & \multicolumn{2}{|c|}{ Phytotoxicity $^{d}$} & \multirow{2}{*}{$\begin{array}{l}\text { Yield } \\
2008\end{array}$} \\
\hline & & 2008 & 2009 & & 2009 & 2010 & \\
\hline & & \multicolumn{2}{|c|}{ Florida scale } & $\%$ Incidence & \multicolumn{2}{|c|}{$\%$} & kg/ha \\
\hline \multicolumn{8}{|l|}{ + tebuconazole } \\
\hline $\begin{array}{l}\text { Prothioconazole } \\
\text { + tebuconazole }\end{array}$ & Clethodim & 3.7 & 6.7 & 55 & 0 & 1 & 1890 \\
\hline $\begin{array}{l}\text { Prothioconazole } \\
+ \text { tebuconazole }\end{array}$ & Sethoxydim & 3.8 & 6.7 & 21 & 0 & 6 & 2380 \\
\hline $\begin{array}{l}\text { Prothioconazole + } \\
\text { tebuconazole }\end{array}$ & Lactofen & 3.3 & 6.5 & 31 & 10 & 7 & 2470 \\
\hline $\begin{array}{l}\text { Prothioconazole } \\
\text { + tebuconazole }\end{array}$ & Acifluorfen & 4.2 & 7.3 & 21 & 5 & 8 & 2020 \\
\hline $\begin{array}{l}\text { Prothioconazole } \\
\text { + tebuconazole }\end{array}$ & Imazethapyr & 3.0 & 6.8 & 39 & 0 & 0 & 1500 \\
\hline $\begin{array}{l}\text { Prothioconazole } \\
\text { + tebuconazole }\end{array}$ & Imazapic & 3.5 & 6.9 & 17 & 0 & 1 & 2080 \\
\hline $\begin{array}{l}\text { Prothioconazole } \\
+ \text { tebuconazole }\end{array}$ & $2,4-D B$ & 3.5 & 7.0 & 16 & 1 & 9 & 1510 \\
\hline LSD (0.05) & & 1.0 & 0.6 & 31 & 1 & 2 & 780 \\
\hline \multicolumn{8}{|c|}{$\begin{array}{l}\text { a Fungicides and rates: pyraclostrobin at } 0.27 \mathrm{~kg} \text { ai/ha, tebuconazole at } 0.23 \mathrm{~kg} \text { ai/ha, and the premix of prothioco- } \\
\text { nazole at } 0.084 \mathrm{~kg} \text { ai/ha + tebuconazole at } 0.168 \mathrm{~kg} \text { ai/ha. Herbicides and rates included clethodim at } 0.14 \mathrm{~kg} \text { ai/ha, } \\
\text { sethoxydim at } 0.21 \mathrm{~kg} \text { ai/ha, aciflurofen at } 0.42 \mathrm{~kg} \text { ai/ha, imazapic at } 0.07 \mathrm{~kg} \text { ai/ha, imazethapyr at } 0.07 \mathrm{~kg} \text { ai/ha, } \\
\text { lactofen at } 0.22 \mathrm{~kg} \text { ai/ha, or } 2,4-\mathrm{hB} \text { at } 0.42 \mathrm{~kg} \text { ai/ha. } \\
\text { b Florida leaf spot scoring system where } 1=\text { no leaf spot, and } 10=\text { plants completely defoliated and dead because of } \\
\text { leaf spot. Values of } 1 \text { through } 4 \text { on the scale reflect increasing incidence of leaflets with spots, and occurrence of } \\
\text { spots in lower versus upper canopy of the plots. Values } 4 \text { through } 10 \text { reflect increasing levels of defoliation. } \\
\text { c Loci of southern stem rot were counted immediately after peanut plants were inverted. A locus represented } 31 \mathrm{~cm} \\
\text { or less of linear row with one or more plants infected with S. rolfsii. Percent incidence based on number of loci/12.7 } \\
\mathrm{m} \text { rows. } \\
\text { d Peanut phytotoxicity ratings (leaf chlorosis and necrosis) ratings were taken } 7 \text { days after treatment. Peanut injury } \\
\text { was visually estimated on a scale of } 0 \text { to } 100 \text { ( } 0 \text { indicating no leaf chlorosis or necrosis and } 100 \text { indicating complete } \\
\text { peanut kill), relative to the non-treated control. }\end{array}$} \\
\hline
\end{tabular}

Table 8. Disease control and peanut response to fungicide-herbicide combinations in south Texas. ${ }^{a}$

Although early-season rainfall was below normal in 2009, September rainfall was above normal leading to conditions for late-season development of high levels of foliar diseases. No differences were noted between the non-treated control and any herbicide with respect to early leaf spot control (Table 8). All fungicides alone or in combination with herbicides resulted in less early leaf spot than the non-treated control. When fungicides were compared alone or in combination, pyraclostrobin alone resulted in less early leaf spot than the combination of 


\begin{tabular}{|c|c|c|c|}
\hline & $\begin{array}{l}\text { Southern } \\
\text { blight }^{\mathrm{b}}\end{array}$ & Leaf spot ${ }^{c}$ & Yield \\
\hline \multirow[t]{2}{*}{ Herbicide } & 2008 & 2010 & 2010 \\
\hline & $\%$ Incidence & $\begin{array}{l}\text { Florida } \\
\text { scale }\end{array}$ & $\mathrm{Kg} / \mathrm{ha}$ \\
\hline \multicolumn{4}{|l|}{ Herbicide } \\
\hline No herbicide & 24 & 6.5 & 3635 \\
\hline Aciflurofen & 13 & 7.6 & 3047 \\
\hline Clethodim & 16 & 6.6 & 3302 \\
\hline Imazapic & 13 & 6.8 & 3581 \\
\hline Imazethapyr & 15 & 7.4 & 3387 \\
\hline Lactofen & 17 & 7.3 & 3048 \\
\hline Sethoxydim & 15 & 6.8 & 3240 \\
\hline $2,4-D B$ & 28 & 6.8 & 3461 \\
\hline LSD (0.05) & $\mathrm{NS}^{\mathrm{c}}$ & 0.5 & NS \\
\hline \multicolumn{4}{|l|}{ Fungicide } \\
\hline No fungicide & 22 & 8.8 & 2834 \\
\hline Pyraclostrobin & 16 & 6.1 & 3490 \\
\hline Tebuconazole & 17 & 6.5 & 3401 \\
\hline $\begin{array}{l}\text { Prothioconazole + } \\
\text { tebuconazole }\end{array}$ & 16 & 6.5 & 3627 \\
\hline LSD (0.05) & $N S^{d}$ & 0.5 & 419 \\
\hline
\end{tabular}

a Fungicides and rates: pyraclostrobin at $0.27 \mathrm{~kg}$ ai $/ \mathrm{ha}$, tebuconazole at $0.23 \mathrm{~kg}$ ai/ $/ \mathrm{ha}$, and the premix of prothioconazole at $0.084 \mathrm{~kg}$ ai $/$ ha plus tebuconazole at $0.168 \mathrm{~kg}$ ai $/ \mathrm{ha}$. Herbicides and rates included clethodim at $0.14 \mathrm{~kg}$ ai/ha, sethoxydim at $0.21 \mathrm{~kg}$ ai/ha, aciflurofen at $0.42 \mathrm{~kg}$ ai $/$ ha, imazapic at $0.07 \mathrm{~kg}$ ai/ha, imazethapyr at $0.07 \mathrm{~kg}$ ai/ha, lactofen at $0.22 \mathrm{~kg}$ ai $/ \mathrm{ha}$, or $2,4-\mathrm{DB}$ at $0.42 \mathrm{~kg}$ ai/ha.

${ }^{b}$ Loci of southern stem rot were counted immediately after peanut plants were inverted. A locus represented $31 \mathrm{~cm}$ or less of linear row with one or more plants infected with S. rolfsii. Percent incidence based on number of loci/12.7 $\mathrm{m}$ rows.

c Florida leaf spot scoring system where 1 = no leaf spot, and $10=$ plants completely defoliated and dead because of leaf spot. Values of 1 through 4 on the scale reflect increasing incidence of leaflets with spots, and occurrence of spots in lower versus upper canopy of the plots. Values 4 through 10 reflect increasing levels of defoliation.

${ }^{d}$ Abbreviation: NS, not significant at the $5 \%$ level of significance.

Table 9. Disease control and peanut response to herbicides and fungicides in south Texas. ${ }^{\text {a }}$

pyraclostrobin plus imazapic while tebuconazole alone resulted in less leaf spot than tebuconazole plus either imazapic or aciflurofen. No differences were noted between prothioconazole plus tebuconazole alone or in combination with any herbicides. 
Weather conditions in 2010 were conducive for development of early leaf spot (Table 7). When herbicides were compared, aciflurofen, imazethapyr, and lactofen resulted in greater early leaf spot than where no herbicide was used (Table 9). All fungicides resulted in less early leaf spot than where no fungicide was used.

\subsubsection{Early leaf spot control in central Texas}

Early leaf spot data was collected only in 2008 and neither fungicide nor herbicide effects were significant. Due to dry conditions, early leaf spot pressure was moderate and there were no differences with any factors (Table 10). Management of early and late leaf spot of peanut is essential for peanut production in most areas of the world [59]. In the southeastern United States, control of these diseases is heavily reliant upon multiple fungicide applications $[59,84]$ while far fewer applications are necessary in the southwestern United States $[53,56,85]$.

\subsubsection{Southern blight control}

Control of southern blight was not significant for any factor in 2008; however, in 2010 there was a fungicide by herbicide interaction. Since peanut were not dug in 2009, no southern blight ratings were taken. In 2008, no differences were noted with respect to development of southern blight (Table 8). In 2010, under low to moderate pressure, sethoxydim alone produced the highest levels of southern blight with over $85 \%$ disease incidence (Table 9). No differences were noted between fungicides alone or the combinations of a fungicide with a herbicide.

\subsubsection{Sclerotinia blight control}

Sclerotinia blight control was significant for both fungicides in both years; whereas herbicides did not impact disease control. Sclerotinia blight pressure was moderate to heavy in each year (Table 10). In 2008, fluazinam provided the best control of Sclerotinia blight compared with the non-treated control while both boscalid and fluazinam reduced Sclerotinia blight compared to the non-treated control in 2009. Fluazinam has provided good to excellent disease control depending on the rate applied [86-88]. Smith et al. [89] reported in field studies that the application of boscalid or fluazinam that preceded the largest incremental increase in disease incidence provided the best control of disease or increased yield. They advised that disease advisories or intensive scouting should be used to determine when epidemics initiate so that a fungicide can be applied prior to infection.

\subsection{Peanut phytotoxicity with tank mix combinations}

In south Texas, peanut phytotoxicity ratings were recorded in 2009 and 2010 and an herbicide by fungicide interaction was observed in each year. In 2009, lactofen alone or in combination with any fungicide resulted in the greatest amount of foliar chlorosis or necrosis (Table 8). The addition of a fungicide to lactofen reduced phytotoxicity 10 to $64 \%$ compared with lactofen alone. Lactofen is classified as a diphenyl ether (cell membrane disruptor), which interferes with protoporphyrinogen IX oxidase and causes accumulation of protoporphyrin IX [90]. Protoporphyrinogen IX is a potent photosensitizer that generates high levels of singlet oxygen 


\begin{tabular}{|c|c|c|c|}
\hline \multirow{2}{*}{ Fungicide } & \multirow{2}{*}{ Leaf spot ${ }^{b}$} & \multicolumn{2}{|c|}{ Sclerotinia blight c } \\
\hline & & 2008 & 2009 \\
\hline & Florida scale & & \\
\hline None & 5.4 & 31.9 & 39.3 \\
\hline Boscalid & 5.1 & 24.3 & 18.5 \\
\hline Fluazinam & 5.6 & 16.6 & 12.7 \\
\hline LSD (0.05) & $N S^{d}$ & 13.9 & 8.0 \\
\hline \multicolumn{4}{|c|}{$\begin{array}{l}\text { a Fungicides and rates: boscalid at } 0.49 \mathrm{~kg} \text { ai/ha and fluazinam at } 0.88 \mathrm{~kg} \text { ai/ha. Herbicides and rates included clethodim } \\
\text { at } 0.14 \mathrm{~kg} \text { ai/ha, sethoxydim at } 0.21 \mathrm{~kg} \text { ai/ha, aciflurofen at } 0.42 \mathrm{~kg} \text { ai } / \mathrm{ha} \text {, imazapic at } 0.07 \mathrm{~kg} \text { ai/ha, imazethapyr at } 0.07 \\
\mathrm{~kg} \text { ai/ha, lactofen at } 0.22 \mathrm{~kg} \text { ai/ha, or } 2,4-\mathrm{DB} \text { at } 0.42 \mathrm{~kg} \text { ai } / \mathrm{ha} \text {. Data combined over fungicides due to a lack of interaction. } \\
\text { b Leaf spot assessed using the Florida } 1-10 \text { scale where } 1=\text { no disease and } 10=\text { completely dead. Leaf spot present only } \\
\text { in } 2008 \text {. } \\
\text { c Loci of Sclerotinia blight were counted just prior to peanut plants being inverted. A locus represents } 31 \mathrm{~cm} \text { or less of } \\
\text { linear row with one or more plants exhibiting disease symptoms or signs of } S \text {. minor. } \\
\text { d NS, not significant at the } 5 \% \text { level of probability. }\end{array}$} \\
\hline
\end{tabular}

Table 10. Foliar disease and Sclerotinia blight control with fungicides in central Texas. ${ }^{\mathrm{a}}$

in the presence of molecular oxygen and light, leading to light-induced oxidative breakdown of cell constituents [90]. Aciflurofen, also a diphenyl ether herbicide, caused injury similar to lactofen; however, this injury was not as great as that observed with lactofen (Table 8). Peanut and soybean (Glycine max L.) tolerance to aciflurofen and lactofen is based on metabolism, which often results in some leaf bronzing and spotting of leaves and plant growth can be temporarily reduced $[79,91]$.

In 2010, aciflurofen and lactofen exhibited similar phytotoxicity symptoms as exhibited in 2009; however, more phytotoxicity overall was noted with other fungicide-herbicide combinations than was seen in 2009. This increase in phytotoxicity was probably due to the addition of Agridex to all treatments in 2010, which was not added in 2008 or 2009. Phytotoxicity was noted with pyraclostrobin, which is never seen (authors personal observations). Pyraclostrobin and prothioconazole plus tebuconazole combinations with herbicides were more phytotoxic than tebuconazole combinations with herbicides. With tebuconazole, other than aciflurofen or lactofen, only the combination of tebuconazole plus 2,4-DB resulted in observed phytotoxcity. However, with pyraclostrobin or prothioconazole plus tebuconazole, phytotoxicity resulted from combinations with either clethodim, sethoxydim, imazethapyr, or imazapic in addition to aciflurofen or lactofen (Table 8).

\subsection{Peanut yield with tank mix combinations}

In south Texas, there was a fungicide by herbicide interaction for peanut yield in 2008; therefore, data are presented as an interaction while in 2010 only fungicide treatment was significant. In 2008, no treatments affected peanut yield when compared with the non-treated control (Table 8). Only pyraclostrobin alone or tebuconazole plus 2,4-DB resulted in an increase in yield over the non-treated control. The lack of response to fungicides is probably related to 


\begin{tabular}{|c|c|c|c|}
\hline \multirow{2}{*}{ Herbicide } & \multirow{2}{*}{ Fungicide } & \multicolumn{2}{|c|}{ Yield } \\
\hline & & 2008 & 2009 \\
\hline & & \multicolumn{2}{|c|}{$\mathrm{Kg} / \mathrm{ha}$} \\
\hline- & - & 2720 & 1985 \\
\hline Clethodim & - & 2713 & 2099 \\
\hline Clethodim & Fluazinam & 3408 & 3337 \\
\hline Clethodim & Boscalid & 2973 & 3060 \\
\hline Sethoxydim & - & 2930 & 2351 \\
\hline Sethoxydim & Fluazinam & 2778 & 2930 \\
\hline Sethoxydim & Boscalid & 2865 & 4240 \\
\hline- & Fluazinam & 3060 & 2865 \\
\hline- & Boscalid & 3971 & 4402 \\
\hline LSD (0.05) & & $N S^{b}$ & 855 \\
\hline
\end{tabular}

a Fungicides and rates: boscalid at $0.49 \mathrm{~kg}$ ai/ ha and fluazinam at $0.88 \mathrm{~kg}$ ai $/ \mathrm{ha}$. Herbicides and rates included clethodim at $0.14 \mathrm{~kg}$ ai/ha and sethoxydim at $0.21 \mathrm{~kg}$ ai/ $/ \mathrm{ha}$.

${ }^{b}$ NS, Not significant at the $5 \%$ level.

Table 11. Peanut yield as influenced by fungicide and herbicide alone and in combinations in central Texas. ${ }^{\mathrm{a}}$

the hot, dry conditions during the growing season and relatively low disease pressure. In 2010, all fungicides improved peanut yield over the non-treated control (Table 9).

In central Texas, there was no difference with any factor in 2008; however, a significant fungicide by herbicide interaction was observed in 2009. In 2008, there were no differences with any factor for yield while in 2009 there was a fungicide by herbicide interaction; however, yields were extremely variable (Table 11). Damicone and Jackson [92] reported that yield reductions of over $50 \%$ can occur following severe outbreaks of Sclerotinia blight. All boscalid or fluazinam treatments improved peanut yield over the non-treated control . Boscalid alone or in combination with sethoxydim produced greater yield than fluazinam alone or fluazinam in combination with sethoxydim. This agrees with the results of Smith et al. [89] who reported that in both field and greenhouse studies, boscalid performed marginally better than fluazinam.

\section{Conclusions of using tank mix combinations on weed efficacy and peanut response}

Adding fungicides to either clethodim or sethoxydim did not have an effect on annual grass efficacy. No phytotoxicity was noted on peanut and yield was not affected with any gramini- 
cide -fungicide combinations. Lancaster et al. [8] reported that pyraclostrobin and tebuconazole did not reduce the amount of ${ }^{14} \mathrm{C}$-labled clethodim or sethoxydim absorbed in large crabgrass. Although tebuconazole did not reduce efficacy of either graminicide in the field, pyraclostrobin reduced efficacy of clethodim and sethoxydim in some instances. They concluded that reduced absorption was not the mechanism for reduced large crabgrass control but may be the result of a biological response or a chemical interaction. Pyraclostrobin is a strobilurin fungicide which inhibits fungal respiration and acts systemically within the plant [93]. Therefore, the formulated product is not likely to remain on leaf surfaces and interfere with herbicide absorption $[8,9]$. With Palmer amaranth, antagonism was noted $33 \%$ of the time with aciflurofen plus either pyraclostrobin or tebuconazole and 2,4-DB plus pyraclostrobin. Horse purslane also exhibited reduced control with herbicide-fungicides while smellmelon showed no effects of these combinations. Peanut leaf phytotoxicity was most evident with combinations that included aciflurofen or lactofen but this is to be expected since these two herbicides can cause bronzing and leaf spotting when applied alone.

\section{Conclusion of tank mix combinations on disease control and peanut response}

Control of early leaf spot was reduced with pyraclostrobin plus imazapic combinations compared with pyraclostrobin alone in two of three years while pyraclostrobin plus either sethoxydim or lactofen, tebuconazole plus either clethodim or aciflurofen or the premix of prothioconazole plus tebuconazole in combination with aciflurofen reduced leaf spot control over the respective fungicide in one of three years. Fungicide-herbicide combinations did not affect southern blight or Sclerotinia blight disease development over the respective fungicide alone. Peanut phytotoxicity was greatest with aciflurofen or lactofen combinations. Under early leaf spot and southern blight or Sclerotinia blight disease pressure, no negative response was noted for peanut yield with any fungicide-herbicide combinations over the respective fungicide alone.

Many variables can affect interactions of herbicides with fungicides. Adjuvant selection, herbicide and fungicide rate, commercial formulation, active ingredient, spray volume, water quality, and environmental conditions can affect interactions [61]. Applying a higher rate of the herbicide that may be adversely affected can compensate for interactions [94-96]. Applying ammonium sulfate with bentazon reduced the negative effect of adding bentazon to clethodim or sethoxydim $[97,98,99]$. Differential response to clethodim has been noted when applied with different formulations of chlorothalonil [66]. Applying graminicides in higher spray volumes can hasten the negative influence of herbicides and fungicides on weed control by graminicides $[66,100,101]$. Environmental conditions that affect plant response to herbicides or fungicides can influence the magnitude of interactions. Negative effects of interactions associated with the efficacy of systemic herbicides, especially graminicides, are increased when grasses are stressed and the physiological processes that reduce absorption and translocation occur [63,102-105]. 


\section{Acknowledgements}

The National Peanut Board through the Texas Peanut Producers Board provided funds for this research. Kevin Brewer, Dwayne Drozd, Lyndell Gilbert, Bill Klesel, and Ira Yates provided technical assistance.

\section{Author details}

W. James Grichar ${ }^{1 *}$, Peter A. Dotray ${ }^{2}$ and Jason E. Woodward ${ }^{3}$

*Address all correspondence to: w-grichar@tamu.edu

1 Texas A\&M AgriLife Research, Corpus Christi, TX, USA

2 Texas Tech University, Texas A\&M AgriLife Research, Lubbock,TX, USA

3 Texas Tech University, Texas A\&M AgriLife Extension Service, Lubbock, TX, USA

\section{References}

[1] Anonymous. World Geography of the Peanut, University of Georgia. 2004-01-02. http://www.lanra.uga.edu/peanut/knowledgebase/ (accessed 22 Aug 2012.

[2] Seijo G, Lavia GI, Fernandez A, Krapovickas A, Ducasse DA, Bertioli DJ, Moscone EA. Genomic relationships between the cultivated peanut (Arachis hypogaea, Leguminosae) and its close relatives revealed by double GISH. American Journal of Botany. 2007;94(12) 1963-1971.

[3] Hammons R. Early History and Origin of the Peanut. In: Tripp L. (ed.) Peanuts-Culture and Uses. Roanoke: American Peanut Research and Education Association; 1973. p17-45.

[4] Gregory WC, Gregory MP, Krapovickas A, Smith BW, Yarbrough JA. Structures and Genetic Resources of Peanuts. In: Tripp L. (ed.) Peanuts-Culture and Uses. Roanoke: American Peanut Research and Education Association; 1973. p47-134.

[5] Hammons R. Genetics of Arachis hypogaea. In: Tripp L. (ed.) Peanuts-Culture and Uses. Roanoke: American Peanut Research and Education Association; 1973. p135-173.

[6] Sturke DG, Buchanan GA. Cultural Practices. In: Tripp L. (ed.) Peanuts-Culture and Uses. Roanoke: American Peanut Research and Education Association; 1973. p299-326. 
[7] Soyatech. Peanut facts. http://www.soyatech.com/peanutfacts.htm (accessed $27 \mathrm{Au}$ gust, 2012.

[8] Lancaster SH, Jordan DL, York AC, Burke IC, Corbin FT, Sheldon YS, Wilcut JW, Monks DW. Influence of selected fungicides on efficacy of clethodim and sethoxydim. Weed Technology 2005;19 397-403.

[9] Lancaster SH, Jordan DL, York AC, Wilcut JW, Monks DW, Brandenburg RL. Interactions of clethodim and sethoxydim with selected agrichemicals applied to peanut. Weed Technology 2005;19 456-461.

[10] Wilcut JW, York AC, Grichar WJ, Wehtje GR. The Biology and Management of Weeds in Peanut (Arachis hypogaea). In: Pattee HE and Stalker HT. (eds.) Advances in Peanut Science. Stillwater: American Peanut Research and Education Society; 1995. p207-244.

[11] Henning RJ, Allison AH, Tripp LD. Cultural Practices. In Pattee HE and Young CT. (eds.) Peanut Science and Technology. Yoakum: American Peanut Research and Education Society; 1982. p123-138.

[12] Walker RH, Wells LW, McGuire JA. Bristly starbur (Acanthospermum hispidum) interference in peanuts (Arachis hypogaea). Weed Science. 1989;37 196-200.

[13] Brecke BJ, Colvin DL. Weed Management in Peanuts. In Pimentel D. (ed.) CRC Handbook of Pest Management in Agriculture. Boca Raton: CRC Press; 1991. p239-251.

[14] Webster TM. Weed Survey-Southern States. Proceedings of Southern Weed Science Society 2005;58 291-306.

[15] Anonymous. Weed Identification Guide. Southern Weed Science Society, Champaign, IL.1999.

[16] Correll DS, Johnson, MC. Manual of the Vascular Plants of Texas. University of Texas at Dallas. Richardson, TX;1979 p555-556.

[17] Grichar WJ, Besler BA, Lemon RG, Brewer KD. Weed management and net returns using soil-applied and postemergence herbicide programs in peanut (Arachis hypogaea L.). Peanut Science 2005;32 25-31.

[18] Buchanan GA, Murray DS, Hauser EW. Weeds and Their Control in Peanuts. In; Pattee HE, Young CT. (eds.) Peanut Science and Technology. Yoakum: American Peanut Research and Education Society, Incorporated; 1982. p206-249.

[19] Anonymous. Crop Protection Reference. 26th Edition. Chemical \& Pharmaceutical Press, Inc. New York. http://www.greenbook.net. (accessed 28 September 2012).

[20] Chamblee RW, Thompson L Jr, Bunn TM. Management of broadleaf signalgrass (Brachiaria platyphylla) in peanuts (Arachis hypogaea). Weed Science 1982;30 40-44. 
[21] Wilcut JW, Wehtje GR, Walker RH. Economics of weed control in peanuts (Arachis hypogaea) with herbicides and cultivations. Weed Science 1987;35 711-715.

[22] Wilcut JW, Wehtje GR, Patterson MG. Economic assessment of weed control systems for peanuts (Arachis hypogaea). Weed Science 1987;35 433-437.

[23] Brecke BJ, Currey WL. Weed control in peanuts with ethalfluralin. Peanut Science 1980;7 124-127.

[24] Dotray PA, Keeling JW, Grichar WJ, Prostko EP, Lemon RG. Peanut response to ethalfluralin, pendimethalin, and trifluralin preplant incorporated. Peanut Science 2004;30 34-37.

[25] Prostko EP, Johnson WC III, Mullinix BG Jr. Annual grass control with preplant incorporaed and preemeergence applications of ethalfluralin and pendimethalin in peanut (Arachis hypogaea). Weed Technology 1999;15 36-41.

[26] Johnson WC III, Mullinix BG Jr. Peanut seedling response to dinitroaniline herbicides applied preplant incorporated and preemergence. Peanut Science 1999;26 28-32.

[27] Merkle MG. Weed control. In: Peanut Production in Texas. College Station: Texas Agricultural Experiment Station; 1975. p50-52.

[28] Greer HA, Tripp LD, Santleman PW. The influence of environmental conditions on weed control and Spanish peanut injury by herbicides. In: Proceedings Southern Weed Science Society. 1969;22 145-149.

[29] Grichar WJ, Colburn AE. Effect of dinitroaniline herbicides upon yield and grade of five runner cultivars. Peanut Science 1993;20 126-128.

[30] Grichar WJ, Colburn AE, Baughman PA. Yellow nutsedge (Cyperus esculentus) control in peanut (Arachis hypogaea) as influenced by method of metolachlor application. Weed Technology 1996;10 278-281.

[31] Anonymous. Dual Magnum label SCP 816A-L1N 0403. Syngenta Crop Protection. Greensboro 2004.

[32] Cardina J, Swann CW. Metolachlor effects on peanut growth and Development. Peanut Science 1988;15 57-60.

[33] Wehtje G, Wilcut JW, Hicks TV, McGuire J. Relative tolerance of peanuts to alachlor and metolachlor. Peanut Science 1988;15 53-56.

[34] Osborne BT, Shaw DR, Ratliff RL. Response of selected soybean (Glycine max) cultivars to dimethenamid and metolachlor in hydroponic conditions. Weed Technology $1995 ; 9$ 178-181.

[35] Mueller TC, Shaw DR, Witt WW. Relative dissipation of acetochlor, alachlor, metolachlor, and SAN 582 from three surface soils. Weed Technology 1999;13 341-346. 
[36] Cole TA, Wehtje GR, Wilcut JW, Hicks TV. Behavior of imazethapyr in soybeans (Glycine max), peanuts (Arachis hypogaea), and selected weeds. Weed Science 1989;37 639-644.

[37] Wilcut JW, Walls FR Jr, Norton DN. Imazethapyr for broadleaf weed control in peanuts (Arachis hypogaea). Peanut Science 1991;18 26-30.

[38] Wilcut JW, Walls FR Jr, Norton DN. Weed control, yield, and net returns using imazethapyr in peanuts (Arachis hypogaea). Weed Science 1991;39 238-242.

[39] York AC, Wilcut JW. Potential for Cadre and Pursuit applied to peanuts to carryover to cotton in North Carolina and Georgia. Proceedings Beltwide Cotton Conference; 1995. p.602.

[40] Wilcut JW, Richburg JS III, Eastin EF, Wiley GR, Walls FR Jr, Newell S. Imazethapyr and paraquat systems for weed management in peanut (Arachis hypogaea). Weed Science 1994;42 601-607.

[41] Wilcut JW, Richburg JS III, Wiley G, Walls FR Jr., Jones SR, Iverson MJ. Imidazolinone herbicide systems for peanut (Arachis hypogaea L.). Peanut Science 1994;21 23-28.

[42] Richburg JS III, Wilcut JW, Wehtje GR. Toxicity of foliar and/or soils applied AC 263,222 to purple (Cyperus rotundus) and yellow nutsedge (C. esculentus). Weed Science 1993;42 398-402.

[43] Wilcut JW, York AC, Wehtje GR. The control and interaction of weeds in peanut (Arachis hypogaea). Review of Weed Science 1994;6 177-205.

[44] Nester PR, Grichar WJ. Cadre combinations for broadleaf weed control in peanut. Proceedings Southern Weed Science Society 1993;46 317.

[45] Grichar WJ, Colburn AE, Nester PR. Weed control in Texas peanut with Cadre. Proceedings American Peanut Research and Education Society 1994;26 70.

[46] Wilcut JW, Eastin EF, Richburg JS III, Vencil WK, Wells FR, Wiley G. Imidazolinone systems for southern weed management in resistant corn. Proceedings Weed Science Society America 1993;33 5.

[47] Grey TL, Bridges DC, Prostko EP, Eastin EF, Johnson WC III, Vencil WK, Brecke BJ, MacDonald GE, Tredaway Ducar JA, Everest JW, Wehtje GR, Wilcut JW. Residual weed control with imazapic, diclosulam, and flumioxazin in southeastern peanut (Arachis hypogaea). Peanut Science 2003;30 22-27.

[48] Richburg JS III, Wilcut JW, Colvin DL, Wiley GR. Weed management in southeastern peanut (Arachis hypogaea) with AC 263,222. Weed Technology 1996;10 145-152.

[49] Culbreath AK, Brenneman TB, Bondari K, Reynolds KL, McLean HS. Late leaf spot, southern stem rot, and peanut yield responses to rates of cyproconazole and chlorothalonil applied alone and in combination. Plant Disease 1995;79 1121-1124. 
[50] Hagan AK, Rivas-Davila ME, Bowen KL, Wells L. Comparison of fungicide programs for the control of early leaf spot and southern stem rot on selected peanut cultivars. Peanut Science 2004;31 22-27.

[51] Chiteka ZA, Gorbet DW, Shokes FM, Kucharek TA, Knauft DA. Components of resistance to late leafspot in peanut. I. Levels and variability-implications for selection. Peanut Science 1988;15 25-30.

[52] Brenneman TB, Murthy AP, Csinos AS. Activity of tebuconazole on Sclerotium rolfsii and Rhizoctonia solani, two soilborne pathogens of peanut. Plant Disease 1991;75 744-747.

[53] Grichar WJ, Besler BA, Jaks AJ. Use of azoxystrobin for disease control on Texas peanut. Peanut Science 2000;27 83-87.

[54] Bowen KL, Hagan AK, Weeks JR. Number of tebuconazole applications for maximizing disease control and yield of peanut in grower's fields in Alabama. Plant Disease 1997;81 927-931.

[55] Branch WD, Brenneman TB. Pod yield and stem rot evaluation of peanut cultivars treated with tebuconazole. Agronomy Journal 1996;88 933-936.

[56] Besler BA, Grichar WJ, Brewer KD, Baring MR. Assessment of six peanut cultivars for control of Rhizoctonia pod rot when sprayed with azoxystrobin or tebuconazole. Peanut Science 2003;30 49-52.

[57] Culbreath AK, Brenneman TB, Bondari K, Reynolds KL, McLean HS. Late leaf spot, southern stem rot, and peanut yield responses to rates of cyproconazole and chlorothalonil applied alone and in combination. Plant Disease 1995;79 1121-1124.

[58] Dutzmann S, Suty-Heinze A. Prothioconazole: a broad spectrum demethylation inhibitor (DMI) for arable crops. Pflanzenschutz-Nachr Bayer 2004;57 249-264.

[59] Culbreath AK, Kemerait, RC Jr, Brenneman TB. Management of leaf spot diseases of peanut with prothioconazole applied alone or in combination with tebuconazole or trifloxystrobin. Peanut Science 2008;35 149-158.

[60] Anonymous. Variety Guide. In: The Peanut Grower February 2010; p10-18.

[61] Jordan DL, Gurinderbir SC, Lancaster SH, Beam JB, York AC. Defining Interactions of Herbicides with Other Agrochemicals Applied to Peanut. In Soloneski S., Larramendy M. (eds.) Herbicides, Theory, and Applications. Rijeka: InTech; 2011. p73-92.

[62] Barret M. Interactions of Herbicides and other Agrochemicals in Plants: Interactions in Mixtures with other Herbicides and with Safeners, Fungicides, Insecticides, and Nematicides. In Altman NJ (ed.) Pesticide Interactions in Crop Production: Beneficial and Deleterious Effects. Boca Raton: CRC Press; 1993. p113-132.

[63] Green MJ. Herbicide antagonism at the whole plant level. Weed Technology 1989;3 217-226. 
[64] Hatzois KK, Penner D. Interaction of herbicides with other agricultural chemicals in higher plants. Review of Weed Science 1985;1 1-64.

[65] Putnam AR, Penner D. Pesticide interactions in higher plants. Residue Review 1974;50 73-110.

[66] Jordan DL, Culpepper AS, Grichar WJ, Ducar JT, Brecke BJ, York AC. Weed control with combinations of selected fungicides and herbicides applied postemergence to peanut (Arachis hypogaea L.). Peanut Science 2003;30 1-7.

[67] Moore JD, Banks PA. Interactions of foliarly applied herbicides on three weed species in peanut (Arachis hypogaea). Weed Science 1991;39 614-621.

[68] Simpson CE, Baring MR, Schubert AM, Black MC, Melouk HA, Lopez Y. Registration of 'Tamrun OL 02' peanut. Crop Science 2006;46 1813-1814.

[69] Beasley J, Baldwin J. Peanut cultivar options and descriptions. 2009 http://www.uga/ commodities/fieldcrops/peanuts/production/cultivardescription.html. (accessed 21 September 2012.

[70] Simpson CE, Baring MR, Schubert AM, Melouk HA, Lopez Y, Kirby JS. Registration of 'Olin' peanut. Crop Science 2003;43 1880-1881.

[71] Gorbet DW, Tillman BL. Registration of 'Florida 07' peanut. Journal of Plant Registration 2009;3 14-18.

[72] Rodriquez-Kabana R, Backman PA, Williams JC. Determination of yield losses to Sclerotium rolfsii in peanut fields. Plant Disease Reporter 1975;59 855-858.

[73] Grichar WJ. Control of Texas panicum (Panicum texanum) and southern crabgrass (Digitaria ciliaris) in peanuts (Arachis hypogaea) with postemergence herbicides. Peanut Science 1991;18 6-9.

[74] Grichar WJ. Control of Palmer amaranth (Amaranthus palmeri) in peanut (Arachis hypogaea) with postemergence herbicides. Weed Technology 1997;11 739-743.

[75] Grichar WJ. Horse purslane (Trianthema portulacastrum) control in peanut (Arachis hypogaea). Weed Technology 1997;7 199-202.

[76] Grichar WJ. Horse purslane (Trianthema portulacastrum), smellmelon (Cucumis melo), and Palmer amaranth (Amaranthus palmeri) control in peanut with postemergence herbicides. Weed Technology 2007;21 688-691.

[77] Thompson AM, Rosales-Robles E, Chandler JM, Nester PR, Tingle CH. Crop tolerance and weed management systems in imidazolinone-tolerant corn (Zea mays L.). Weed Technology 2005;19 1037-1044.

[78] Grichar WJ. Citronmelon (Citrullus lanatus var. citroides) control in Texas peanut (Arachis hypogaea) using postemergence herbicides. Weed Technology 2001;15 481-484. 
[79] Dotray PA, Grichar WJ, Baughman TA, Prostko EP, Grey TL, Gilbert LV. Peanut (Arachis hypogaea L.) response to lactofen at various postemergence timings. Peanut Science 2012;39 9-14.

[80] Richburg JS III, Wilcut JW, Grichar WJ. Response of runner, Spanish, and Virginia peanut ciultivars to imazethapyr. Peanut Science 2006;33 47-52.

[81] Dotray PA, Baughman TA, Keeling JW, Grichar WJ, Lemon RG. Effect of imazapic application timing on Texas peanut (Arachis hypogaea). Peanut Science.2001;15 26-29.

[82] Wilcut JW, Richburg JS III, Wiley GL, Walls FR Jr. Postemergence AC 263,222 systems for weed control in peanut (Arachis hypogaea). Weed Science 1996;44 615-621.

[83] Grichar WJ, Sestak DC, Besler BA. Effects of various timings of 2,4-DB on runnertype peanut development and yield. Peanut Science 1997;24 105-106.

[84] Nutter FW Jr., Shokes FM. Management of Foliar Diseases Caused by Fungi. In Melouk HA, Shokes FM. (eds.) Peanut Health Management. St. Paul: The American Phytopathological Society; 1995. p65-73.

[85] Grichar WJ, Jaks AJ, Woodward J. Using prothioconazole plus tebuconazole for foliar and soilborne disease control in Texas peanut. Crop Management 2010 doi:10.1094/ CM-2010-0405-02-RS.

[86] Damicone JP, Jackson KE. Disease and yield responses to fungicides among peanut cultivars differing in reaction to Sclerotinia blight. Peanut Science 1996;23 81-85.

[87] Smith FD, Phipps PM, Stipes RJ. Agar plate, soil plate, and field evaluation of fluazinam and other fungicides for control of Sclerotinia minor on peanut. Plant Disease 1991;75 1138-1143.

[88] Smith FD, Phipps PM, Stipes RJ. Fluazinam: A new fungicide for control of Sclerotinia blight and other soilborne pathogens of peanut. Peanut Science 1992;19 115-120.

[89] Smith DL, Garrison MC, Hollowell JE, Isleib TG, Shew BB. Evaluation of application timing and efficacy of the fungicides fluazinam and boscalid for control of Sclerotinia blight of peanut. Crop Protection 2008;27 823-833.

[90] Duke SO, Lydon J, Becerril JM, Sherman TD, Lehnen LP Jr., Matsumoto H. Protoporphyrinogen oxidase-inhibiting herbicides. Weed Science 1991;39 465-473.

[91] Harris JR, Gossett BJ, Murphy TR, Toler JE. Response of broadleaf weeds and soybeans to the diphenyl ether herbicides. Journal of Production Agriculture 1991;4 407-411.

[92] Damicone JP, Jackson KE. Effects of application method and rate on control of Sclerotinia blight of peanut with iprodione and fluazinam. Peanut Science 2001;28 28-33. 
[93] Clough JM, Godfrey CRA. The Strobilurin Fungicides. In: Hutson D, Miyamoto J. (eds.) Fungicidal Activity Chemical and Biological Approaches to Plant Protection. New York: J. Wiley; 1998. p109-148.

[94] Chernicky JP, Slife FW. Effects of sublethal concentrations of bentazon, fluazifop, haloxyfop, and sethoxydim on corn (Zea mays). Weed Science 1986;34 171-174.

[95] Rhodes GN Jr, Coble HD. Influence of application variables on antagonism between sethoxydim and bentazon. Weed Science 1984;32 436-441.

[96] Rhodes GN Jr, Coble HD. Influence of bentazon on absorption and translocation of sethoxydim in goosegrass. Weed Science 1984;32 595-597.

[97] Penner, D. The impact of adjuvants on herbicide antagonism. Weed Technology $1989 ; 3$ 227-231.

[98] Jordan DL. Influence of adjuvants on the antagonism of gramancides by broadleaf herbicides. Weed Technology 1995;9 741-747.

[99] Jordan DL, York AC. Effects of ammonium fertilizers and BCH 81508 S on antagonism with sethoxydim plus bentazon mixtures. Weed Technology 1989;3 450-454.

[100] Buhler DD, Burnside OC. Effect of application factors on the phytotoxicity of fluazifop-butyl, haloxyfop-methyl, and sethoxydim. Weed Science 1984;32 574-583.

[101] Kells JJ, Wanamarta G. Effect of adjuvant and spray volume on quackgrass (Agropyron repens) control with selective postemergence herbicides. Weed Technology 1987;1 129-132.

[102] Burke IC, Price AJ, Wilcut JW, Jordan DL, Culpepper AS, Ducar JT. Annual grass control in peanut (Arachis hypogaea) with clethodim and imazapic. Weed Technology 2004;18 88-92.

[103] Burke IC, Wilcut JW. Physiological basis for antagonism of clethodim by imazapic on goosegrass [Eleusine indica (L.) Gaertn.]. Pesticide Biochemistry Physiology 2003;76 37-45.

[104] Wanamarta G, Penner D. Identification of efficacious adjuvants for sethoxydim and bentazon. Weed Technology 1989;3 60-66.

[105] Wanamarta G, Penner D, Kells JJ. The basis of bentazon antagonism on sethoxydim absorption and activity. Weed Science 1989;37 400-404. 